Research papers

\title{
Environmental and coastline changes controlling Holocene carbon accumulation rates in fjords of the western Strait of Magellan region
}

\author{
Francisco Ríos $^{\mathrm{a}, *}$, Rolf Kilian ${ }^{\mathrm{a}, \mathrm{b}}$, Carina B. Lange ${ }^{\mathrm{c}, \mathrm{d}, \mathrm{e}, \mathrm{f}}$, Oscar Baeza-Urrea ${ }^{\mathrm{a}}$, Helge W. Arz ${ }^{\mathrm{g}}$, \\ Mark Zindorf $^{\mathrm{h}}$, Ricardo De Pol-Holz ${ }^{\mathrm{i}}$, Frank Lamy ${ }^{\mathrm{j}}$ \\ ${ }^{a}$ Universität Trier, Lehrstuhl für Geologie Fachbereich Geographie/Geowissenschaften (FB VI), Campus II, Behringstrasse 21, 54286, Trier, Germany \\ ${ }^{\mathrm{b}}$ Universidad de Magallanes, Avenida Bulnes, 01855, Punta Arenas, Chile \\ ${ }^{\mathrm{c}}$ Departamento de Oceanografía, Universidad de Concepción, Casilla 160-C, Concepción, Chile \\ d Centro de Investigación Oceanográfica COPAS Sur-Austral, Universidad de Concepción, Barrio Universitario, Concepción, Chile \\ e Centro de Investigación Dinámica de Ecosistemas Marinos de Altas Latitudes (IDEAL), Universidad Austral de Chile, Campus Isla Teja, Valdivia, Chile \\ ${ }^{\mathrm{f}}$ Scripps Institution of Oceanography, La Jolla, CA, 92037, USA \\ ${ }^{\mathrm{g}}$ Leibniz-Institut für Ostseeforschung Warnemünde, Seestraße 15, 18119, Rostock-Warnemünde, Germany \\ ${ }^{\mathrm{h}}$ Ifremer - Centre de Brest, Laboratoire Environnement Profond, 29280, Plouzané, France \\ ${ }^{\mathrm{i}}$ Centro de Investigación GAIA-Antártica (CIGA) and Network for Extreme Environment Research (NEXER), Universidad de Magallanes, Avenida Bulnes, 01855, Punta \\ Arenas, Chile \\ ${ }^{\mathrm{j}}$ Alfred-Wegener-Institut Helmholtz-Zentrum für Polar und Meeresforschung, 27570, Bremerhaven, Germany
}

\section{A R T I C L E I N F O}

\section{Keywords:}

Patagonian fjord sediments

Paleoproductivity

Carbon accumulation

Biogenic carbonate

Marine transgression

Holocene

\begin{abstract}
A B S T R A C T
Organic-rich sediments of the southernmost Chilean Pacific coast and its fjord system constitute an important component of the global marine carbon budget. Sediment records from Trampa and Caribe bays and Churruca fjord in the western Magellan fjord system have been analyzed with the goal of understanding the factors controlling carbon accumulation and its regional fluctuation throughout the Holocene. The individual response in paleoproductivity at the different sites and related variations in accumulation rates document a very complex interplay among local and regional-scale environmental changes, and coastline elevation across the Holocene. Shallow sill basins close to the Pacific coast, as the ones studied here, are particularly sensitive to these processes, having responded with strong productivity changes throughout the Holocene.

A Bayesian mixed model approach, using sediment archived provenance proxies, indicates that components of terrestrial plants and soils washed-out into these basins contribute with a variable proportion (20-80 wt $\%)$ of the total accumulated organic carbon. Accumulation rates of terrestrial carbon increase with the amount of precipitation in the hyper-humid mountain area, but also reflect distinct Holocene plant successions as well as longterm development of soil and vegetation cover that strongly overprint the direct precipitation impact. Over the Holocene accumulation rates of biogenic carbonate and aquatic-marine organic carbon range between 5 and 118 $\mathrm{kg} \mathrm{m}^{-2} \mathrm{kyr}^{-1}$ and $0.3-20 \mathrm{~kg} \mathrm{~m}^{-2} \mathrm{kyr}^{-1}$, respectively. This variability depends on water column structure and conditions, which are regulated by the degree of marine transgression as a function of post glacial sea level rise and isostatic uplift as well as precipitation-related surface water freshening. In the Bahia Trampa record, a significant change in accumulation rates indicates a marine transgression at ca. $12.2 \mathrm{kyr} \mathrm{BP}$, when the global sea level was 60-70 m lower than today and eustatic rise overcame isostatic rebound rates. In Caribe and Trampa records, $\mathrm{CaCO}_{3}$ accumulation rates were higher at ca. $7 \mathrm{kyr}$ BP. The Churruca record shows organic carbon accumulation rates up to $36.2 \mathrm{~kg} \mathrm{~m}^{-2} \mathrm{kyr}^{-1}$ during the early Holocene.
\end{abstract}

\section{Introduction}

The factors controlling fluxes and coastal aquatic-marine storage of organic carbon $(\mathrm{OC})$ as well as the accumulation of biogenic carbonate in shelf sediments, and particularly in fjord regions, are crucial for the global carbon budget. A recently review highlights the importance of

\footnotetext{
* Corresponding author.

E-mail addresses: phrano@gmail.com (F. Ríos), clange@udec.cl (C.B. Lange), baezaurr@uni-trier.de (O. Baeza-Urrea), helge.arz@io-warnemuende.de (H.W. Arz), mark@zindorf.de (M. Zindorf), ricardo.depol@umag.cl (R. De Pol-Holz), Frank.Lamy@awi.de (F. Lamy).
} 
these sensitive systems needing intensive investigation (Bianchi et al., 2020). Smith et al. (2015) estimated that the contribution of OC in fjord sediments is equivalent to $\sim 10 \mathrm{wt} \%$ of the annual marine OC burial. The Pacific continental margin of Patagonia includes the most extended fjord region in the world (total area of $240,000 \mathrm{~km}^{2}$ and $84,000 \mathrm{~km}$ of coastline; Pantoja et al., 2011). Despite its vast extension, only few studies constrain the recent accumulation of aquatic-marine and terrestrial OC, and biogenic carbonate in sediments of the Patagonian fjord ecosystems (Aracena et al., 2011; Lafon et al., 2014; Sepúlveda et al., 2011; Silva et al., 2011; Vargas et al., 2011). The spatial distribution of OC sources of north Patagonia surface sediments indicate a gradient of terrestrial OC contents from $62 \mathrm{wt} \%$ to $32 \mathrm{wt} \%$ in a fjord-ocean transect (González et al., 2019).

On longer time-scales, Holocene fjord sediment records show variable contribution of OC from terrestrial vegetation sources, in particular derived from dense rainforests and peatlands $\left(\mathrm{OC}_{\mathrm{terr}}\right.$ : 30 to $70 \mathrm{wt} \%$; Bertrand et al., 2017, 2012; Harada et al., 2013; Lamy et al., 2010; Rebolledo et al., 2015). The amount of terrestrial input to these fjord sediments depends on local and regional factors. Local geomorphology, in particular ratios between the areas of terrestrial catchments and related fjord basins (Cui et al., 2017; Hinojosa et al., 2014; Smeaton and Austin, 2017), development of drainage conditions as well as long-term development of soils with distinct chemical compositions related to bedrock lithologies, play a major role. Regional to local factors as climate conditions and the altitudinal distribution of the vegetation zone influence the transport of $\mathrm{OC}_{\text {terr }}$, which often depends on precipitation rates and locallly associated water pathways (Lamy et al., 2010). Moreover, damages of terrestrial ecosystems after the deposition of tephra from explosive volcanic eruptions cause enhanced plant decay up to a millennium scale leading to increased delivery and deposition of OC $_{\text {terr }}$ (Kilian et al., 2006; Korup et al., 2019; Mohr et al., 2017).

Organic carbon from aquatic-marine sources $\left(\mathrm{OC}_{\mathrm{aq}}\right)$ in Patagonian fjords principally derives from the local production of "brackish water" organic matter, which is related to sea surface temperatures (SSTs), the supply of nutrients, and the depth of the photic zone (Cuevas et al., 2019; Kilian et al., 2013a). Macronutrients (nitrate and phosphate) are mainly introduced by oceanic water with higher salinities and locally reduced thermohaline gradients (Cuevas et al., 2019; Ríos et al., 2016). Moreover, continental runoff transports other macronutrients such as dissolved silica as well as micronutrients (i.e., iron) into the fjords, exerting an additional influence on the "brackish water" productivity (Iriarte et al., 2014; Torres et al., 2011, 2014).

A significant amount of carbon storage in fjord sediments concerns the accumulation of biogenic carbonate that contributes to the total carbon burial with a regionally and temporally highly variable quantity (Smeaton et al., 2017). Since accumulation of biogenic carbonate in fjords is sourced from planktic and benthic organisms, the relative contribution of both depends on thermohaline and nutrient conditions within the whole water column (González et al., 2013; Milzer et al., 2013; Rüggeberg et al., 2016). In particular, benthic foraminifera constitute up to $38 \mathrm{wt} \%$ of the inorganic carbon in Arctic fjord sediments (Pawłowska et al., 2017). In the Magellan fjord system, benthic foraminifera species distribution is strongly controlled by oceanic input from the Pacific in the west and the freshwater input from land (Hromic et al., 2006). This freshwater input occurs as a superficial outflow, which in addition to variations in runoff from rivers and streams, and meltwater from glaciers, is controlled by the variable strength of the Southern Westerly Winds (SWW) (Kilian et al., 2013a).

Variability in SWW intensities exhibit a significant positive correlation with the amount of precipitation on the elevated windward side of the Andes (Garreaud et al., 2013), and thus also with the freshwater discharge and local glacier mass balances. The related physical and chemical denudation rates control the terrestrial supply of micronutrients (Breuer et al., 2013a) and consequently, affect the aquatic primary production in the fjord region (Kilian et al., 2013a; Ríos et al., 2016). Based on the correlation between precipitation and regional
SWW intensities, precipitation-sensitive proxies in sediment cores have been used to reconstruct Holocene variations in width, strength and latitudinal position of the SWW belt (Kilian and Lamy, 2012 and references therein).

Records from southwestern Patagonia $\left(52^{\circ}-53^{\circ} \mathrm{S}\right)$ evidence highest precipitation rates during the early Holocene between $\mathrm{ca}$. 11 to $8.5 \mathrm{kyr}$ BP (Kilian and Lamy, 2012; Lamy et al., 2010). These implications have been partially controversially discussed (Moreno et al., 2010; Fletcher and Moreno, 2012). At these latitudes, recent studies from eastern Patagonia, which presents an inverse correlation between precipitation and zonal wind intensities (Garreaud et al., 2013), indicate a humid phase in the early Holocene between ca. 11.2 to $10.1 \mathrm{kyr}$ BP while increased SWW intensity occurred from ca.10.1-8.3 kyr BP (Zolitschka et al., 2019). Composite analysis of pollen data from sites east of the Andes support the hypothesis that storm tracks weakened throughout Patagonia $\left(41^{\circ}-55^{\circ} \mathrm{S}\right)$ between $c a .13-10 \mathrm{kyr} \mathrm{BP}$, followed by stronger storm tracks in southern Patagonia than in northern Patagonia between ca.10-7 kyr BP (Nanavati et al., 2019).

In this context, records from the westernmost fjord region may contribute to a better understanding of the long-term variability and location of the SWW during the Late Glacial and the Holocene (Aracena et al., 2015; Harada et al., 2013). Here, we present three new sediment records from the fjord region around the western sector of the Strait of Magellan (Fig. 1a). The investigated cores represent examples of regional variations in accumulation rates and aquatic paleoproductivity since the Late Glacial. More specifically, we use organic and inorganic geochemical proxies and physical properties of the sediment cores with the aim of understanding the evolution and control factors of OC accumulation. We further infer the effects of marine transgression and the related coastline changes on marine productivity and OC accumulation as well as biogenic carbonate burial in the southern Patagonian fjords.

\section{Study area}

Next to the Pacific entrance of the Strait of Magellan there is an extended water system with estuarine characteristics that serves as an important transition area between land and ocean environments, including fjords, estuaries and other coastal semi-enclosed ecosystems. The infilled postglacial sediments represent valuable archives for reconstructing past environmental changes in this region including paleoproductivity. The site-specific productivity and sedimentation dynamics strongly depend on local bathymetries of variably deep basins and subaquatic sills (Table 1), which at present control - and during the past constrained - the influence of open marine water masses and a westward expanding surface outflow of fresher water from the inner fjords.

\subsection{Description of sites}

The locations of the investigated sediment cores are shown in Fig. 1b. Two of them are located in the southwestern sector of the Reina Adelaida Archipelago, next to the Pacific Ocean within previously unnamed small bays on the Contreras and Pacheco islands, now denominated Bahía Caribe and Bahía Trampa, respectively (Fig. 2a). These areas should have experienced pronounced regional coastline changes during the Holocene. A third sediment core was retrieved from the Churruca fjord, which is located to the southeast of the other two sites at Desolación Island (Fig. 2b).

The catchment areas of the studied basins are dominated by outcrops of the Southern Patagonian Batholith, including plutonites with a composition from granite to gabbro and mafic dikes (Diaz-Michelena and Kilian, 2015; Hervé et al., 2007). Carbonate rocks are absent in the catchment and in the areas surrounding the studied sites. The closest limestone outcrops are located $>70 \mathrm{~km}$ northward from the coastal sites BT and BC on Diego de Almagro Island (Fig. 1 and Suppl. Fig. S1). The vegetation is composed by rain forest patches in favorable sites with 


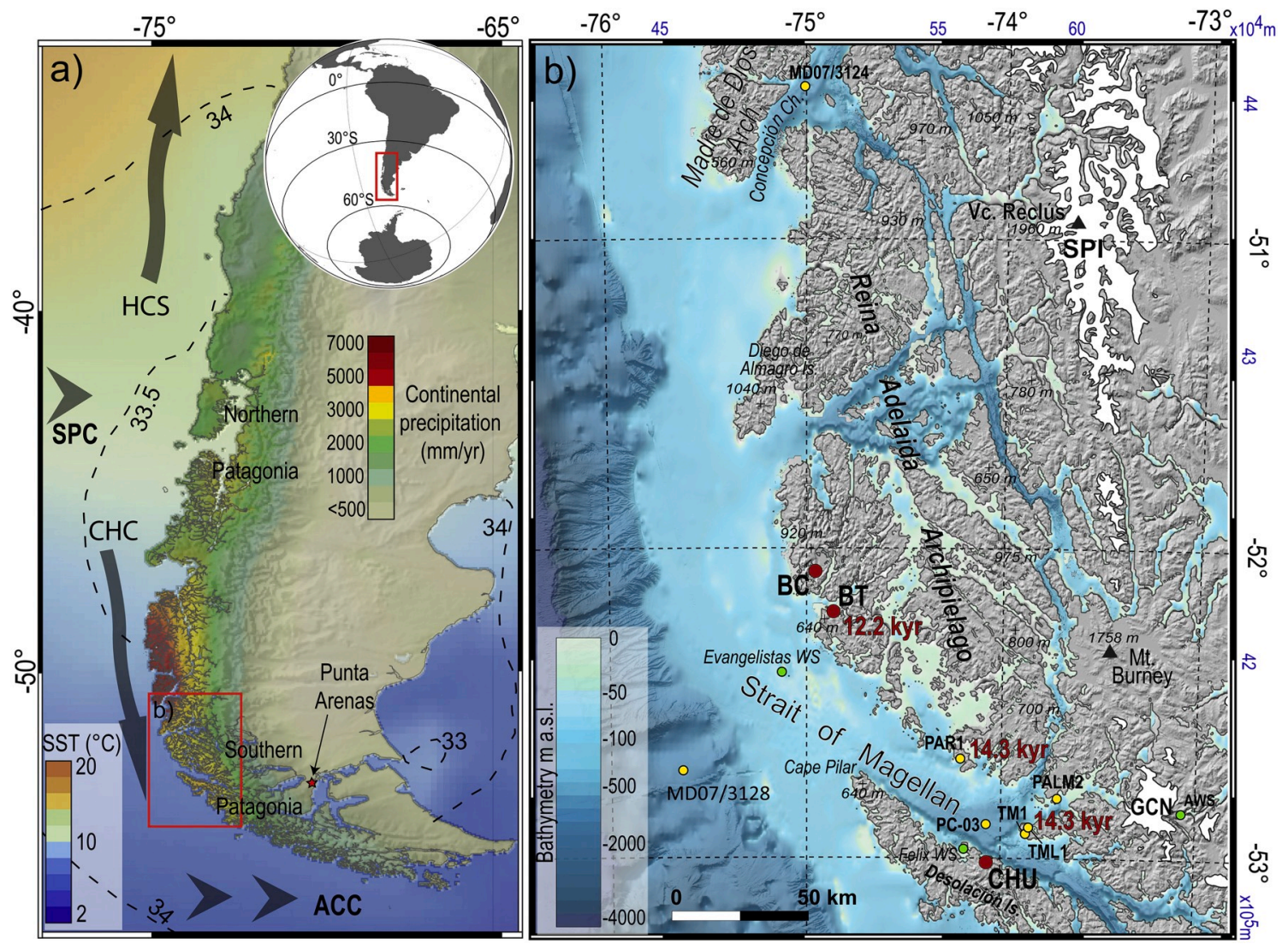

Fig. 1. a) Southernmost South America with average annual precipitation values over Patagonia ( $\mathrm{mm} \mathrm{yr}^{-1}$; New et al., 2001), and modern annual mean sea surface temperature (SST ${ }^{\circ} \mathrm{C}$ ) and salinity (dashed lines in psu) distributions of the surrounding ocean (WOA13, Boyer et al., 2013). Modern ocean surface currents after Strub et al. (2019) include the South Pacific Current (SPC), the northward-branching Humboldt Current System (HCS), southward-branching Cap Horn Current (CHC) and the Antarctic Circumpolar Current (ACC). The red rectangle indicates the study area shown in Fig. 1b b) Red circles refer to the location of the new sediment core sites Bahía Trampa (BT), Bahía Caribe (BC) and Churruca fjord (CHU) presented here. Yellow circles show the position of core sites discussed in the text, and green circles refer to weather stations (WS) and the automatic weather station near Gran Campo Nevado ice field (AWS). Red annotations in kyr indicate the minimum age for the marine transgression in the western sector of the Strait of Magellan (after Lamy et al., 2010 and Kilian et al., 2007a). Topography and bathymetry from GMRT 3.5 (Ryan et al., 2009). Blue annotation indicates the UTM coordinates. Projection UTM18S, datum WGS84. (For interpretation of the references to colour in this figure legend, the reader is referred to the Web version of this article.)

Table 1

Summary of physical characteristics of the three study sites.

\begin{tabular}{|c|c|c|c|c|c|c|c|}
\hline Site & Catchment area $\left(\mathrm{km}^{2}\right)$ & Basin area $\left(\mathrm{km}^{2}\right)$ & Vegetation area $\left(\mathrm{km}^{2}\right)$ & Veg.cover (\%) & Catchment/basin area & Veg./basin area & Sill depth (m a.s.l.) \\
\hline Bahía Trampa & 4.4 & 0.16 & 1.9 & 44 & 27.5 & 11.9 & -3 \\
\hline Bahía Caribe & 3.2 & 0.94 & 0.7 & 20 & 3.4 & 0.7 & -15 \\
\hline Churruca fjord & 3.8 & 0.95 & 2.2 & 55 & 4 & 2.3 & -30 \\
\hline
\end{tabular}

adequate drainage and shelter from wind. In sectors with lower slopes, such as in BT and CHU, there is also development of dwarf shrubs, grass and herbs.

Fig. 2b illustrates the multi-basin estuary of the Churruca fjord where one of the investigated sites is located (CHU). The main basin has a N-S orientation from mouth to head. The three main arms are oriented NWSE following the structural fabrics of the rocks along the MagellanFagnano fault system (Breuer et al., 2013b). The water exchange with the Strait of Magellan is restricted by two sills ( $<36 \mathrm{~m}$ and $<34 \mathrm{~m}$ water depth, WD) separating the inner and outer fjord. In the inner fjord area, a shallow contraction $(<30 \mathrm{~m}$ WD) further restricts the water exchange between the fjord's inner and outer sub-basins. Towards the head of the estuary, a narrow constriction separates the shallow Brazo León sub-basin $(<25 \mathrm{~m}$ WD, Fig. 2b) from the deeper outer basins. The southwestern flanks of the surrounding mountains are up to $650 \mathrm{~m}$ high with slope angles of $15^{\circ}-25^{\circ}$. Physical characteristics are summarized in Table 1.
The Bahía Caribe site (BC) is located in a semi-elliptic basin with a $\mathrm{N}-\mathrm{S}$ orientation located at the head of an elongated fjord in ENE-WSW direction (Fig. 2a-c). The water exchange is restricted by a sill of 15 $\mathrm{m}$ WD, which connects the basin with a narrow inlet $(7 \mathrm{~km}$ length, 0.5 $\mathrm{km}$ width, 200-250 m WD) open to the Pacific Ocean. The freshwater inflow comes from runoff and from a small affluent at the head of the fjord. During the coring operation (austral spring), a very low salinity was measured at the surface ( $3 \mathrm{psu}$ ) increasing strongly with depth to 30 psu at $6 \mathrm{~m} \mathrm{WD}$, from where values of 31 psu remained constant until the bottom at $70 \mathrm{~m}$ WD. Both east and west flanks of this basin display steep slopes $\left(30^{\circ}-50^{\circ}\right)$ with a restricted vegetation cover (Table 1$)$. The lower elevations of the catchment, particularly on the western flank, are characterized by well drained clastic slope deposits and almost totally covered by dense rainforest (Fig. 2c).

The Bahia Trampa site (BT) is a small semi-enclosed shallow bay of $15 \mathrm{~m}$ WD with estuarine conditions (Fig. 2d). It has an elongated shape in NE-SW direction and covers a comparatively smaller area than the 

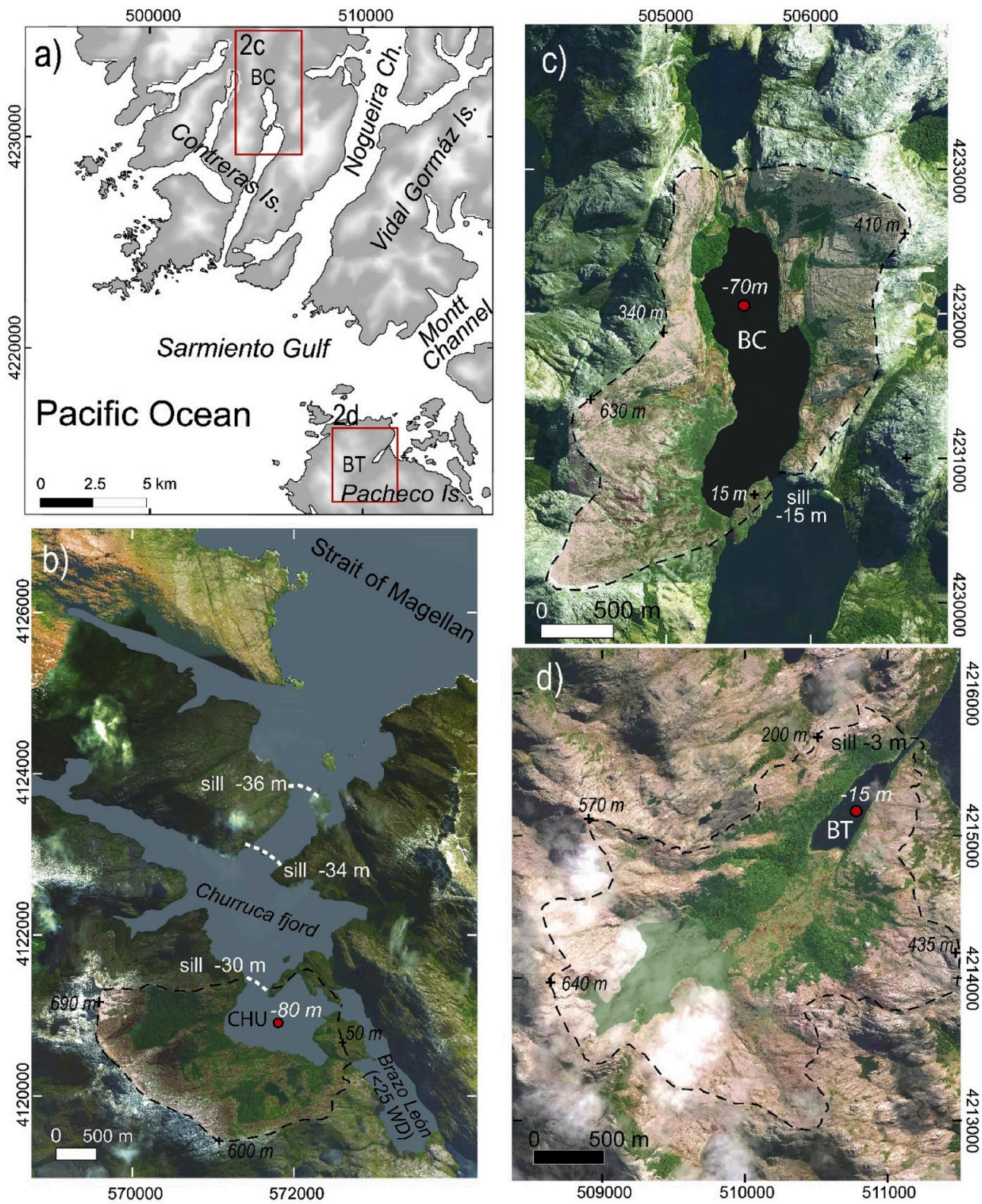

Fig. 2. Detailed maps of the study areas. Red dots indicate coring sites CHU, BC and BT. Water depths of sills and basins are shown as white/black annotations. Black dashed lines refer to catchment areas, and annotations over the line indicate their maximum elevations. a) SW sector of Reina Adelaida Archipelago. Red rectangles show the locations of BC and BT sites. b) Churruca fjord site (CHU) at the south coast of the Strait of Magellan. c) Bahía Caribe core site (BC, Contreras Island) and d) Bahía Trampa core site (BT, Pacheco Island). Projection UTM18S, datum WGS84. Image source Bing Maps - Digital Globe 2015. (For interpretation of the references to colour in this figure legend, the reader is referred to the Web version of this article.)

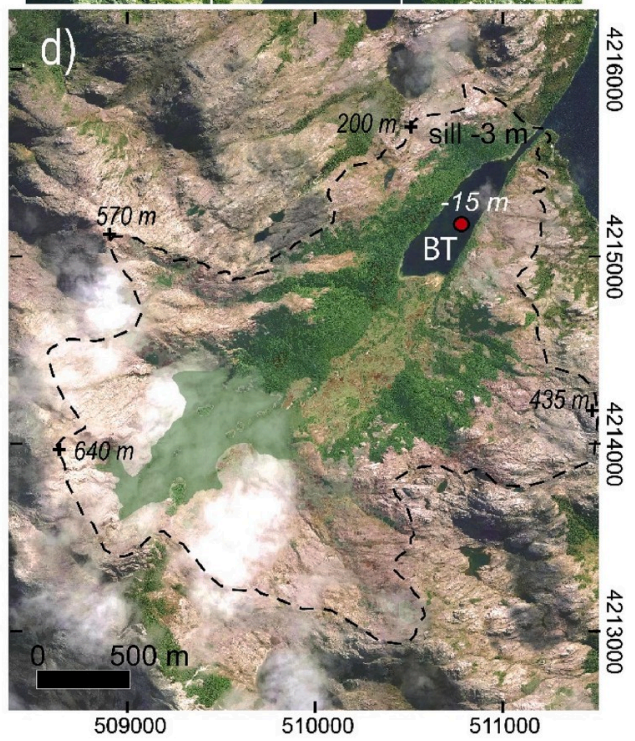

other sites (Table 1). Towards the northeast, a narrow channel (30 m wide and $230 \mathrm{~m}$ long) connects BT with the open fjord system next to the Pacific Ocean. The very shallow depth of this channel (1.5-3 m) restricts the water exchange with the open fjord depending on the tidal water levels. Measured salinities increase from 5 psu at the surface to $30 \mathrm{psu}$ at the bottom of the bay. The southern flank of the catchment reaches up to $50 \mathrm{~m}$ elevation and exhibits inclinations of $15^{\circ}-25^{\circ}$ and is sparely vegetated, while the northern flank has steeper slope angles of $30^{\circ}-35^{\circ}$ and is covered by a dense rainforest (Table 1). At the SW shore, a small river enters the bay (Fig. $2 \mathrm{~d}$ ).

The geomorphological features of the CHU and BC sites are very similar with respect to catchment and basin sizes and ratios. However, the steeper slopes probably restrict the vegetation cover and soil development in BC compared with CHU (Table 1). CHU is characterized as an inner fjord environment with a well-developed vegetation catchment while $\mathrm{BC}$ represents a coastal basin with more restricted terrestrial organic sources. The BT site is also close to the open marine environment, but presents a more extended vegetation cover with a much larger catchment/basin ratio than that of $\mathrm{BC}$ (Table 1).

\subsection{Oceanography and precipitation regime}

At the latitude of the study area $\left(53^{\circ} \mathrm{S}\right)$, the coastal surface water properties are controlled by the Cape Horn Current (CHC) flowing along the Southern Chilean continental margin from around $45^{\circ} \mathrm{S}$ towards the Drake Passage (Fig. 1a; Strub et al., 2019; Lamy et al., 2015). Oceanic waters enter the Magellan fjord system as saline bottom waters (salinity $>33 \mathrm{psu}$ ) below a fresh/brackish surface water layer (salinity 1-32 psu; Aracena et al., 2015; Kilian et al., 2013a; Palma et al., 2014; Valdenegro and Silva, 2003). The thermohaline properties of the brackish layer are mainly controlled by a variable amount of freshwater input and the mixing degree with Pacific waters (Silva and Vargas, 2014). The intensity of this surface freshening changes on seasonal and weekly scales, in particular e.g. after extremely high precipitation events or due to glacier meltwater loaded with glacial clays and snow melting that accumulated on top of adjacent mountains. Surface salinities are generally higher during autumn and winter, while runoff from frequent storms and glacier melting can strongly reduce salinities $(<20 \mathrm{psu})$ during the late spring and summer in the uppermost few meters of the water column (Kilian et al., 2007a, 2013a). 
In the study area, precipitation is driven by the SWW (Garreaud, 2009; Garreaud et al., 2013). The SWW are strongest between $50^{\circ}$ and $55^{\circ} \mathrm{S}$ (Lamy et al., 2010; Saunders et al., 2018). At these latitudes, annual precipitation on the western side of the orographic barrier of the Andes reaches very high values $\left(3,000-10,000 \mathrm{~mm} \mathrm{yr}^{-1}\right.$; Schneider et al., 2003; Weidemann et al., 2018) and decreases strongly towards the east (e.g. $300-400 \mathrm{~mm} \mathrm{yr}^{-1}$ in Punta Arenas, Stolpe and Undurraga, 2016).

Coastline changes during the Holocene are related to global sea level rise and regional vertical movements of the continental crust. The uplift in the investigated region is mainly associated with subduction-related tectonic deformation (Bentley and McCulloch, 2005; Rostami et al., 2000) and isostatic vertical adjustments (McCulloch et al., 2005; Porter et al., 1984). The combination of these factors strongly affected past environmental changes in the Strait of Magellan area, in accordance with the timing and degree of the marine transgressions (Aracena et al., 2015; Kilian et al., 2007a, 2013a).

\section{Material and methods}

\subsection{Sediment coring}

The sediment cores were retrieved onboard RV Gran Campo II during campaigns in 2007 (CHU site) and 2011 (BC and BT sites) after systematic sediment echosounding in each basin. An UWITEC piston corer of $5 \mathrm{~m}$ length and $63 \mathrm{~mm}$ in diameter with internal and removable PVC liners was used for sediment coring. For composite core lengths of more than $5 \mathrm{~m}$, discontinuous drilling was performed. In this case, for the recovery of the deeper core sections, first the sediments were drilled with closed piston corer (piston in place) to a depth determined $1 \mathrm{~m}$ above the base of the previously drilled section. The piston corer was then opened (piston released) and 5 additional meters where drilled with sediment recovery. This was done in order to obtain $\sim 1 \mathrm{~m}$ overlap of single core sections. Additionally, 0.4-1 m long gravity cores were taken to obtain undisturbed records from the uppermost sediment layers. The correlation between single core sections was performed adjusting the sediment depths in agreement with stratigraphic markers observed in the cores and geochemical measurements. The correlation in $\mathrm{BT}$ and $\mathrm{BC}$ records was controlled by high-resolution X-ray fluorescence scanner data on the split sediment cores (Suppl. figs. S2, S3 and S4).

The investigated sediment core from the $\mathrm{CHU}$ fjord $\left(53^{\circ} 03.29^{\prime} \mathrm{S}\right.$, $73^{\circ} 55.76^{\prime} \mathrm{W}$ ) was retrieved at $80 \mathrm{~m}$ WD. Its composite core length is 11.2 $\mathrm{m}$ and consists of three piston core sections (30-517 cm, 430-904 cm and $780-1156 \mathrm{~cm}$ core depths). No gravity core was taken at this site. Therefore, we assume that $30 \mathrm{~cm}$ of the surface sediments were missing during the piston coring operation considering a linear extrapolation of the three uppermost age determinations (see section 3.3) and regional values of sedimentation and accumulation rates during the late Holocene (Kilian and Lamy, 2012). At the BC site $\left(52^{\circ} 04.04^{\prime} \mathrm{S}, 74^{\circ} 55.00^{\prime} \mathrm{W}\right)$, a total sediment core composite of $9.1 \mathrm{~m}$ length was recovered from 70 $\mathrm{m}$ WD. The BC record consists of a superficial gravity core $(0-25 \mathrm{~cm})$ and two piston core sections (25-420 cm and 420-911 cm core depth). From the deepest sector of the BT ( $\left.15 \mathrm{~m} \mathrm{WD}, 52^{\circ} 12.84^{\prime} \mathrm{S}, 74^{\circ} 50.54^{\prime} \mathrm{W}\right)$, a composite sediment core of $9.0 \mathrm{~m}$ length was retrieved. The BT record is composed of a superficial gravity core $(0-26 \mathrm{~cm})$ and three piston core sections (27-367 cm, 369-509 cm and 521-900 cm core depths).

\subsection{Age determinations and age-depth models}

All sediment cores have been inspected for possible tephra layers known to occur in the region. In the CHU record, the $4.15 \mathrm{kyr}$ BP Mt. Burney tephra was identified at $368 \mathrm{~cm}$ sediment depth, by means of its chemical composition and SEM-based typical structure of the included pumices (Kilian et al., 2003, 2013b). The westernmost BT and BC sites seem to be outside of the Holocene tephra distribution areas of the volcanoes Hudson, Aguilera, Reclus and Mt. Burney (Stern, 2008).

Accelerator mass spectrometer radiocarbon ages $\left({ }^{14} \mathrm{C}\right.$ AMS) were determined on plant remains (i.e. wood or leaves) and marine mollusk shells at NOSAMS (Woods Hole Oceanographic Institution, USA), the Department of Earth Systems Sciences of the University of California, Irvine, USA, and MICADAS Laboratory, AWI, Bremerhaven, Germany. Marine shell ages were corrected for a reservoir effect of $500 \mathrm{yr}$. This reservoir age was estimated by the offset between the well-dated 4.15 kyr BP Mt. Burney tephra and the ${ }^{14} \mathrm{C}$ ages at the CHU core. All radiocarbon ages have been calibrated using SHCal13 calibration curve (Table 2; Hogg et al., 2013). Age models and calculations of sedimentation rates (SR in $\mathrm{mm} \mathrm{yr}^{-1}$ ) were performed with CLAM 2.2 software (Blaauw, 2010). All sediment core depths were corrected for virtually instantaneous event layers with $>1 \mathrm{~cm}$ thickness. Such event layers were not considered in the calculations of sedimentation rates.

The age-depth models were based on the composite depths of the cores and the distribution of the calibrated radiocarbon ages (Table 2), using a spline interpolation that considers a smooth factor of 0.3 for $\mathrm{BC}$ and BT, and 0.5 for $\mathrm{CHU}$, in order to adjust the SR at the base of the CHU

Table 2

Radiocarbon ages and calibrated 95\% confidence intervals used for the depth-age models. The SHCal13 curve (Hogg et al., 2013) was used to calibrate the ages. Marine reservoir age $=500$ yrs. UCI $=$ Department of Earth Systems Sciences University of California, Irvine; OS = National Ocean Sciences Accelerator Mass Spectrometry Facility (NOSAMS, Woods Hole Oceanographic Institution). AWI = MICADAS Laboratory, Alfred Wegener Institute.

\begin{tabular}{|c|c|c|c|c|c|}
\hline Core & Core depth $(\mathrm{cm})$ & Laboratory code & ${ }^{14} \mathrm{C}$ age \pm error (yr BP) & Material & Cal. 95\% confidence intervals (yr BP) \\
\hline $\mathrm{CHU}$ & 58 & UCIAMS 82045 & $1325 \pm 15$ & Marine shell & $680-770$ \\
\hline $\mathrm{CHU}$ & 78 & UCIAMS 82046 & $1500 \pm 20$ & Marine shell & $810-870$ \\
\hline $\mathrm{CHU}$ & 138 & UCIAMS 82047 & $2070 \pm 15$ & Marine shell & $1430-1510$ \\
\hline $\mathrm{CHU}$ & 260 & UCIAMS 82048 & $3275 \pm 20$ & Marine shell & $2800-3060$ \\
\hline $\mathrm{CHU}$ & 313 & UCIAMS 82049 & $3730 \pm 15$ & Marine shell & $3430-3640$ \\
\hline $\mathrm{CHU}$ & 345 & UCIAMS 82050 & $4205 \pm 15$ & Marine shell & $4090-4330$ \\
\hline $\mathrm{CHU}$ & 531 & UCIAMS 82051 & $5595 \pm 15$ & Marine shell & $5800-5900$ \\
\hline $\mathrm{CHU}$ & 627 & UCIAMS 82052 & $6935 \pm 15$ & Marine shell & $7170-7290$ \\
\hline $\mathrm{CHU}$ & 803 & OS-74685 & $8160 \pm 35$ & Wood & $8990-9240$ \\
\hline $\mathrm{CHU}$ & 903 & OS-74686 & $8355 \pm 20$ & Wood & $9150-9440$ \\
\hline $\mathrm{CHU}$ & 1080 & OS- 74687 & $9740 \pm 50$ & Wood & $10800-11230$ \\
\hline $\mathrm{BC}$ & 202 & UCIAMS 108165 & $2125 \pm 50$ & Wood & $1930-2300$ \\
\hline BC & 482 & AWI 1352.1.1 & $5417 \pm 57$ & Wood & $6000-6280$ \\
\hline $\mathrm{BC}$ & 714 & UCIAMS 108166 & $8260 \pm 60$ & Wood & $9020-9400$ \\
\hline BT & 123.5 & UCIAMS 108158 & $1350 \pm 15$ & Nothofagus sp. leaf & $1190-1280$ \\
\hline BT & 263 & UCIAMS 108159 & $3395 \pm 15$ & Wood & $3490-3690$ \\
\hline BT & 294.5 & UCIAMS 108160 & $3645 \pm 20$ & Nothofagus sp. leaf & $3840-3980$ \\
\hline BT & 534.5 & UCIAMS 108161 & $6470 \pm 20$ & Wood & $7290-7420$ \\
\hline BT & 685.5 & UCIAMS 108164 & $7560 \pm 90$ & Wood & $8170-8540$ \\
\hline BT & 854.5 & UCIAMS 108162 & $10745 \pm 45$ & Wood & $12560-12730$ \\
\hline
\end{tabular}


core to values more consistent with regional rates for the early Holocene (Lamy et al., 2010; Kilian and Lamy, 2012, Fig. 3, Table 3). The CHU core depth-age model was based on eleven ${ }^{14} \mathrm{C}$ AMS ages and the 4.15 kyr BP Mt. Burney tephra layer (Kilian et al., 2003, 2013b; Stern, 2008). Beside the tephra, one event layer was identified in $\mathrm{CHU}$ core with a total thickness of $12 \mathrm{~cm}$. Three ${ }^{14} \mathrm{C}$ dates (Table 2) allowed to constrain appropriate SR estimations for the BC core. Six event layers were observed in $\mathrm{BC}$ core with a total thickness of $48 \mathrm{~cm}$ (Fig. 3b). The depth-age model of the BT core was based on six ${ }^{14} \mathrm{C}$ ages (Table 2). In BT were identified 12 events layers with a total thickness of $32 \mathrm{~cm}$ (Fig. 3c).

\subsection{Geochemical and physical property analyses}

For geochemical analyses, a volume of $\sim 3 \mathrm{~cm}^{3}$ of sediment was taken every $10 \mathrm{~cm}$ core depth, and additional samples for the event layers. The samples were weighed and dried overnight at $105^{\circ} \mathrm{C}$. The dry samples were weighed again to calculate dry bulk density (DBD) using the formula DBD = wt. (dry) g/sample vol. $\mathrm{cm}^{3}$. The elemental concentrations of total carbon (TC) and total nitrogen $(\mathrm{N})$ were determined with an elemental analyzer VARIO Element III at the University of Trier, Germany. Previous to the analyses, all samples were homogenized using an agate mortar and pestle and subsampled into $20-30 \mathrm{mg}$ portions and placed in tin capsules. The non-carbonate organic carbon (OC) content was determined on a LECO Carbon Sulfur Analyzer (LECO-CS 125) at the Alfred Wegener Institute (AWI), Bremerhaven, Germany. Samples were acidified by direct addition of $\mathrm{HCl}(1 \mathrm{M})$ and dried at $150{ }^{\circ} \mathrm{C}$ overnight. Calcium carbonate was calculated according to the formula: $\mathrm{CaCO}_{3}=$ (TC - OC) x 8.333 with a detection limit of $0.01 \mathrm{wt} \%$ of $\mathrm{CaCO}_{3}$.

Major elements ( $\mathrm{Si}, \mathrm{Al}, \mathrm{Ti}, \mathrm{Fe}, \mathrm{Mn}, \mathrm{Mg}, \mathrm{Ca}, \mathrm{Na}$ and $\mathrm{K}$ ) were measured by Atomic Absorption Spectrometry (AAS; Varian SpectrAA 220) at the University of Trier. About $100 \mathrm{mg}$ of homogenized sediments were dried $\left(105^{\circ} \mathrm{C}\right)$ and fused in Platinum skillets with $400 \mathrm{mg}$ of a flux material (mixture of Lithiumtetraborat, Lithiumcarbonate and Lanthanoxide). Produced glass pearls were dissolved in $40 \mathrm{ml} \mathrm{HCl}(0.5 \mathrm{M})$. Liquids of samples and international standards (MGR-1, SY-2 and JG-2) were measured by AAS. Determined major elements and loss on ignition $\left(1050{ }^{\circ} \mathrm{C}\right)$ resulted in sums of $99-101$ wt $\%$.

The relative variation in the chemical composition was measured with an ITRAX $\mu$ XRF scanner (Croudace et al., 2006) at the Leibniz Institute for Baltic Sea Research, Warnemünde (IOW), Germany. This non-destructive measuring technique allows for semi-quantitative geochemical analysis of split sediment cores with a very high spatial resolution. To avoid evaporation, the core halves were covered with an ultrathin plastic foil before being measured. The XRF measurements of the BT and BC cores were carried out every $2 \mathrm{~mm}$ and obtained with a molybdenum (Mo) X-ray tube, operated with a voltage of $40 \mathrm{kV}$, a current of $10 \mathrm{~mA}$, and $15 \mathrm{~s}$ exposure time. In addition, the used $\mu \mathrm{XRF}$ core scanner took measurements of the coherent and incoherent scattering that depend on the mineralogical composition, water content, OC content and sediment packing density (Croudace et al., 2006). The ratio of the incoherent-coherent scattering (MoInc/MoCoh) can be considered as a good approximation for the content of organic matter, but it needs to be validated by absolute $\mathrm{OC}$ measurements, in particular for sediment sequences with high OC contents (Chague-Goff et al., 2016; Chawchai et al., 2016). The XRF scanning data for BC and BT were smoothed to $10-\mathrm{cm}$ intervals using a fifty-point running average to compare with the lower resolution $\mathrm{OC}$ values.

Scanning results of Ti were normalized by dividing the counts by the coherent/incoherent ratio (Compton/Rayleigh scattering) to minimize the effects of organic matter and water content (Davies et al., 2015) and scaled to match the AAS determinations. This element is present in most lithogenic phases and thus is used as a proxy for inorganic siliciclastic terrestrial contents. $\mu \mathrm{XRF}$ coherent/incoherent normalized counts of bromine $(\mathrm{Br})$ were used as tracers for marine derived organic input, since $\mathrm{Br}$ has a biophilic behavior and is typically enriched in ocean water
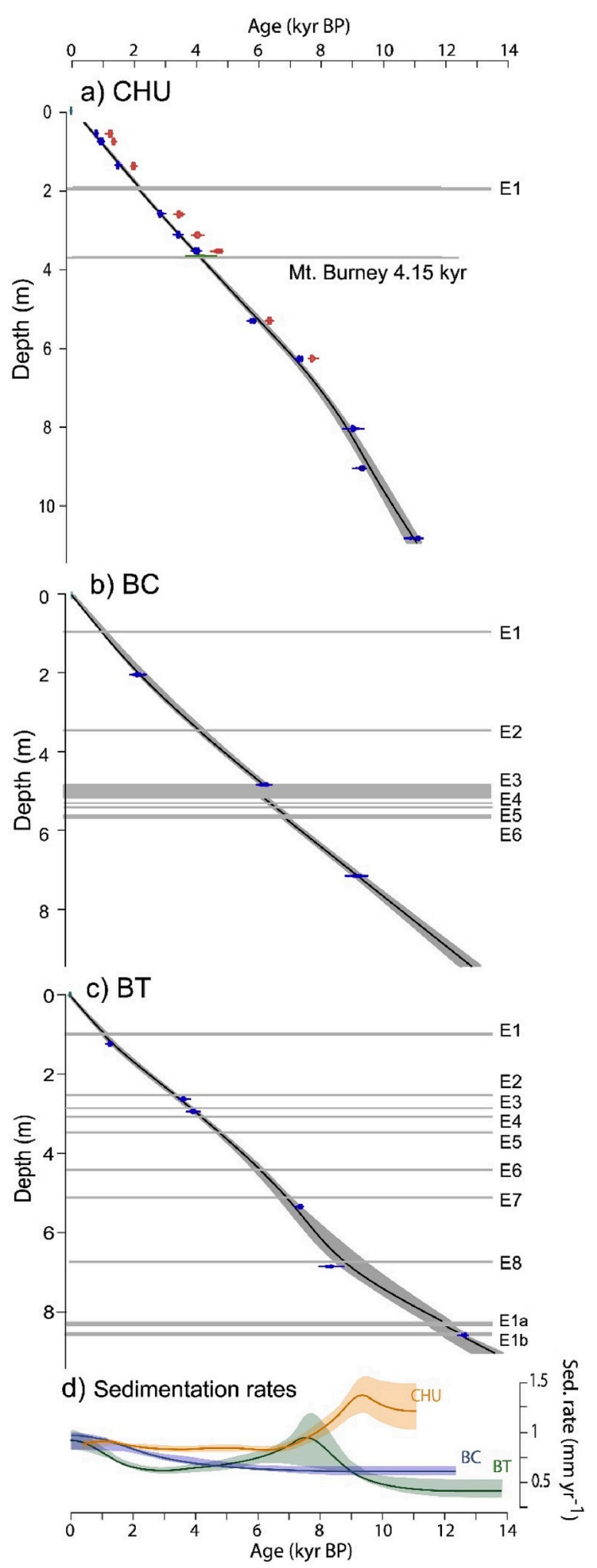

Fig. 3. Age-depth models produced with CLAM 2.2 software. Gray shaded areas indicate $95 \%$ confidence interval. Horizontal gray lines and annotation indicate single depositional events (Suppl. figs. S2, S3 and S4). Calibrated ${ }^{14} \mathrm{C}$ ages are in blue. a) CHU core with smooth spline factor of 0.5. Red areas indicate the calibrated ages without the reservoir effect correction. For BC and BT cores (b and c) a smooth spline factor of 0.3 was used. d) Sedimentation rates without single depositional events. Colored shaded areas indicate $95 \%$ confidence intervals. (For interpretation of the references to colour in this figure legend, the reader is referred to the Web version of this article.) 
Table 3

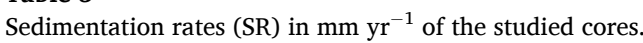

\begin{tabular}{llll}
\hline \multirow{2}{*}{ Time interval (kyr BP) } & \multicolumn{4}{l}{ SR 95\% confidence intervals $\left(\mathrm{mm} \mathrm{yr}^{-1}\right)$} \\
\cline { 2 - 4 } & CHU & BC & BT \\
\hline $0-5.5$ & $0.8-0.9$ & $0.7-0.8$ & $0.7-0.8$ \\
$5.5-8.5$ & $0.9-1.0$ & $0.6-0.7$ & $0.7-1.0$ \\
$8.5-11.7$ & $1.1-1.5$ & $0.6-0.7$ & $0.5-0.6$ \\
$>11.7$ & - & $0.6-0.7$ & $0.3-0.5$ \\
\hline
\end{tabular}

with high nutrient contents (Bertrand et al., 2017; Seidenkrantz et al., 2007; Ziegler et al., 2008). Moreover, calibrated values of Ti and Br were used as tracers for terrestrial and aquatic sources, respectively. As the wt $\%$ OC and wt $\% \mathrm{~N}$ determinations were carried out in $\sim 10 \mathrm{~cm}$ sediment intervals and the scanning data was obtained every $2 \mathrm{~mm}$, the latter dataset was linearly interpolated to the same depth intervals for an appropriate comparison and further calculation of the terrestrial and aquatic fractions.

Terrestrial and aquatic-marine $\mathrm{OC}$ were calculated from OC contents using a Bayesian mixed model (Smeaton and Austin, 2017) with the FRUIT software (Fernandes et al., 2014). The highest value of calibrated $\mathrm{Ti}$ and $\mathrm{Br}$ XRF data were used as end-members for the terrestrial and aquatic-marine sources, respectively. Uncertainties were defined as \pm two standard deviation ( $\pm 2 \mathrm{SD}$ ), assuming a Gaussian distribution. The third tracer was defined by the molar N/C. Terrestrial and aquatic N/C end members followed those given by Lamy et al. (2010): molar N/C = $0.15 \pm 0.02(\mathrm{C} / \mathrm{N}=5.9)$ as the aquatic (micro algal) end-member and $\mathrm{N} / \mathrm{C}=0.032 \pm 0.002(\mathrm{C} / \mathrm{N}=30.3)$ as the terrestrial (vascular plant) end-member.

Accumulation rates (AR in $\mathrm{kg} \mathrm{m}^{-2} \mathrm{kyr}^{-1}$ ) were calculated by multiplying the concentration of each component by the DBD and the SR determined for each sampling interval. In this study, the $A R O_{a q}$ and $A R$ $\mathrm{CaCO}_{3}$ are used as proxies of marine paleoproductivity (Aracena et al., 2015; Lamy et al., 2010). Terrestrial OC primarily originates from nearby land sources and its supply into the fjord basins increases with precipitation and runoff. Therefore, we use $\mathrm{AR} O \mathrm{OC}_{\text {terr }}$ as a freshwater input proxy (Frank et al., 2015; Lamy et al., 2010) considering the long-term relation of $\mathrm{OC}_{\text {terr }}$ input with the vegetation colonization and soil development after deglaciation.

Additionally, the cores were inspected for remains of macroorganisms (e.g. bivalves, gastropods, plants). Granulometric analysis of bulk sediment samples of the BT core was performed by wet sieving and decantation. Previous to the dissolution with $\mathrm{HCl}$, the sand fraction of selected core intervals was screened under 40X magnification Zeiss stereoscope at University of Trier to characterize biogenic rests and lithogenic phases.

\section{Results}

\subsection{Sedimentation rates $(S R)$}

The age-depth models of the studied cores give a maximum age of 14.1 kyr BP for the BT core at $9.0 \mathrm{~m}$ of sediment with an averaged SR of $0.6 \mathrm{~mm} \mathrm{yr}^{-1}$. The $\mathrm{BC}$ record has a maximum age of $12.4 \mathrm{kyr} \mathrm{BP}$ at $9.1 \mathrm{~m}$ sediment depth while CHU record spans over 11.1 kry BP in $11.2 \mathrm{~m}$ of sediment with an average SR of 0.7 and $1.0 \mathrm{~mm} \mathrm{yr}^{-1}$, respectively. Sedimentation rate estimations are summarized in Table 3. Four event

Table 4

Correlation of BC and BT events with 95\% confidence interval modeled ages.

\begin{tabular}{llllll}
\hline BC Core & $\min .95 \%$ & $\max .95 \%$ & BT Core & $\min .95 \%$ & $\max .95 \%$ \\
\hline E1 & 890 & 1050 & E1 & 970 & 1150 \\
E2 & 3970 & 4230 & E3 & 3850 & 4020 \\
E3 & 6040 & 6260 & E6 & 5850 & 6170 \\
E6 & 6660 & 6880 & E7 & 6630 & 7050 \\
\hline
\end{tabular}

layers, identified in the $\mathrm{BT}$ and $\mathrm{BC}$ records, show similar ages and might represent the same regional events. Table 4 presents the modeled age for these events with $95 \%$ confidence interval.

\subsection{Biogenic carbonate concentrations and carbonate fauna}

The BT core is the only record that includes the Late Glacial since $c a$. 14 kyr BP and shows laminated inorganic silts with some coarse sand layers until ca. 12.2 kyr BP. The Late Glacial - early Holocene transition is characterized by laminated sediments. After $12.2 \mathrm{kyr} \mathrm{BP}$, a pronounced increase in $\mathrm{CaCO}_{3}$ is observed (Fig. 4a).

Throughout the early Holocene and during the first half of the midHolocene, the $\mathrm{CaCO}_{3}$ content of the three investigated cores steadily increases up to $26 \mathrm{wt} \%$. After the Neoglacial, CHU and BT records exhibit a similar long-term decrease from $25 \mathrm{wt} \%$ to $10 \mathrm{wt} \%$. In contrast, after $c a .5 .5$ kyr BP the $\mathrm{BC}$ record shows a rapid increase in $\mathrm{CaCO}_{3}$ content from 14 to $38 \mathrm{wt} \%$ and decrease in the last 2 kyr BP (Fig. 4a).

Shell fragments of bivalves were identified in the three cores (Chlamys sp. and Desmophyllum sp.). Identification of benthic foraminifera in the sediments of CHU record showed the presence of Alveophragmiun orbiculatum, Bolivina sp., Bulimina patagonica, Buliminella elegantissima, Cibicides dispars, Discorbis sp., Elphidium sp., Stainforthia fusiformis, Globocassidulina crassa, Guttulina communis, Lagena caudate, Martinotiella communis, Nonionella auris and Spiroloculina tenuis. BT and BC show less diversity with mainly two taxa, Buliminella elegantissima and Nonionella auris and more shell fragment of ostracods. Single deposition layers, with coarse sand observed in BT and BC have

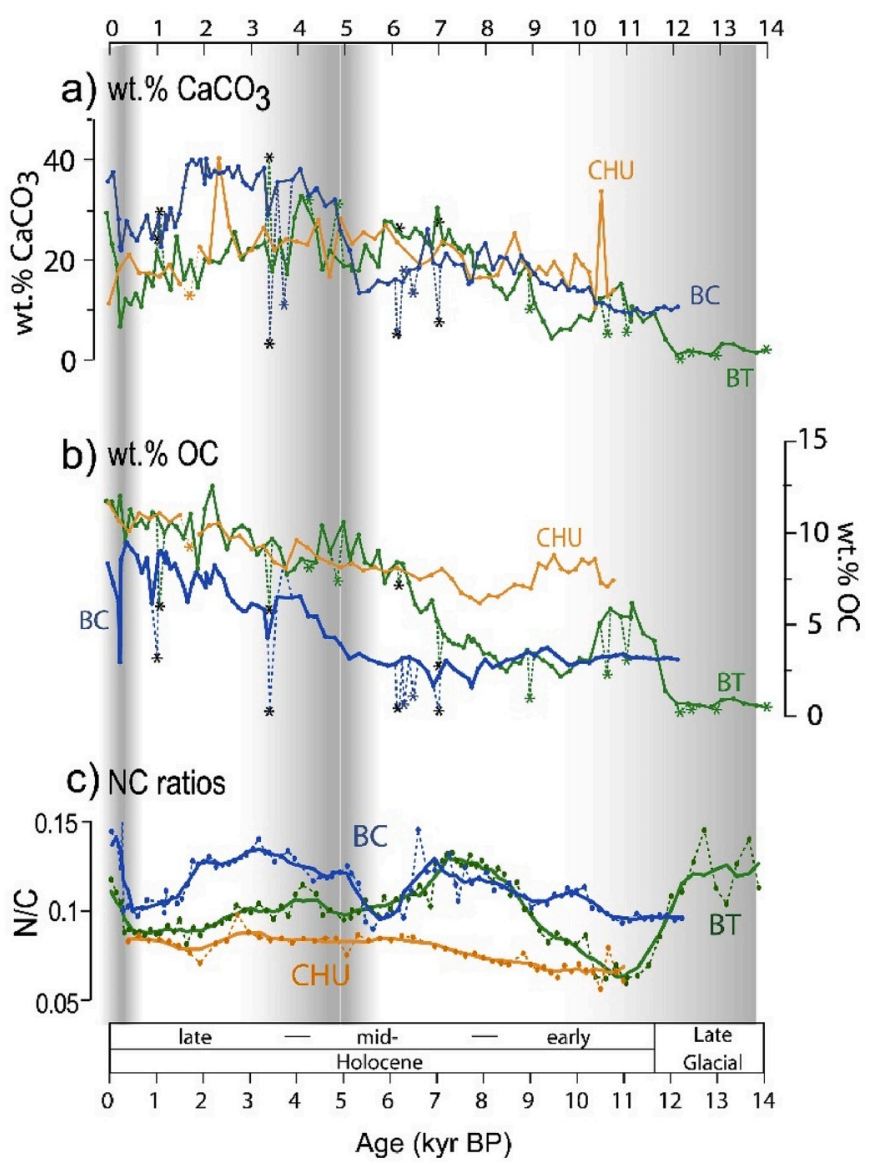

Fig. 4. Measured contents of carbon fractions: a) $\mathrm{CaCO}_{3} \mathrm{wt} \%$, b) $\mathrm{OC} w \mathrm{t} \%$ at the studied sites: Churruca fjord (CHU), Bahia Trampa (BT) and Bahia Caribe (BC). Stars indicate layers related to single depositional events. c) N/C molar ratios. Solid line represents a 3 pts. moving average calculated without the values of the single depositional events. 
fragments of echinoderms and a more diverse foraminifer fauna, including, besides Buliminella sp. and Nonionella sp., Quinqueloculina seminula, Elphidium macellum and Cibicides sp.

\subsection{Organic carbon concentration and molar nitrogen/carbon}

Carbon content differs among the studied cores. During the early Holocene, the CHU core shows relatively high OC contents (9 $\mathrm{wt} \%$ ). Wood remains in a debris flow deposit of BT indicate the presence of vegetation within its catchment at least since $12.6 \mathrm{kyr} \mathrm{BP}$; however, the OC content in this record increases after $12.2 \mathrm{kyr} B P$ and reaches similar values as $\mathrm{CHU}$ during the mid-Holocene. In contrast, the $\mathrm{BC}$ record is characterized by comparatively low contents of OC in the early Holocene, which increases after the Neoglacial (Fig. 4b). In general, all three sites show increasing OC content since the mid-Holocene toward the present.

We consider that the incoherent-coherent scattering ratio (MoInc/ MoCoh) obtained with the $\mu$ XRF core scanner represents a good high resolution proxy for the $\mathrm{OC}$ content. The combined datasets from $\mathrm{BT}$ and BC cores exhibit very good correlations for the MoInc/MoCoh vs wt $\%$ OC $\left(\mathrm{R}^{2}=0.9, \mathrm{n}=198\right.$, Suppl. Fig. S5).

Carbon and nitrogen concentrations are well correlated in the studied cores (Suppl. Fig. S6). Molar N/C ratios show different patterns throughout the Holocene. The $\mathrm{CHU}$ record displays relatively stable and low N/C ratios, whereas N/C ratios of $\mathrm{BC}$ and $\mathrm{BT}$ cores are more variable with similar values between ca. 9 and $5.5 \mathrm{kyr}$ BP (Fig. 4c).

\subsection{Holocene accumulation rates (AR)}

\subsubsection{Total organic carbon}

The studied cores show differences in OC accumulation rates. During the early Holocene, the CHU record is characterized by the highest AR OC (25-35 $\left.\pm 5 \mathrm{~kg} \mathrm{~m}^{-2} \mathrm{kyr}^{-1}\right), 2-3$ times higher than the other two cores (Fig. 5a). The BC record shows relatively stable AR OC (Fig. 5b), while the $\mathrm{BT}$ record is characterized by the rapid increase in AR OC between ca. 12.0-11.6 kyr BP from $3 \pm 1$ to $11 \pm 3 \mathrm{~kg} \mathrm{~m}^{-2} \mathrm{kyr}^{-1}$ (Fig. 5c). Towards the mid-Holocene, AR OC in CHU decreases in $7 \pm 2 \mathrm{~kg} \mathrm{~m}^{-2} \mathrm{kyr}^{-1}$ (Fig. 5a), while the BT record shows a net increase in AR OC of $9 \pm 2 \mathrm{~kg}$ $\mathrm{m}^{-2} \mathrm{kyr}^{-1}$.

\subsubsection{Terrestrial organic carbon}

During the early Holocene, BC and BT records indicate predominant accumulation of $\mathrm{OC}_{\text {terr }}$ (Fig. 6a-b) and relatively high Ti concentrations (Fig. 6c). Throughout the mid-Holocene, Ti contents and AR OC decrease in $\mathrm{BT}$ record, while in $\mathrm{BC}$ core the decrease in the Ti contents after $7.5 \mathrm{kyr} \mathrm{BP}$ occurred together with relatively stable $\mathrm{AR} \mathrm{OC}_{\text {terr }}$ around $7.5 \pm 0.5 \mathrm{~kg} \mathrm{~m}^{-2} \mathrm{kyr}^{-1}$ (Fig. 6). Coarse bioclastic and siliciclastic depositional events occurred during the mid-Holocene in the BT and BC cores and they may have had a further influence on sedimentation dynamics in the records. Particularly in the BT core, the deposition of a coarse layer at $7.05 \mathrm{kyr} \mathrm{BP}$ was followed by an increase in $\mathrm{AR} \mathrm{OC}_{\text {terr. }}$. The onset of the Neoglacial period is characterized by the decrease of AR $\mathrm{OC}_{\text {terr }}$ and $\mathrm{Ti} / \mathrm{Al}$ ratios in $\mathrm{BC}$ and $\mathrm{BT}$ records (Fig. 6 and Suppl. Fig. S8).

\subsubsection{Biogenic carbonate and aquatic-marine organic carbon}

The three sites show an increment in $\mathrm{AR} \mathrm{CaCO}_{3}$ during the early Holocene, which continues throughout the first half of the mid-Holocene in the $\mathrm{BC}$ and $\mathrm{BT}$ records (Fig. $7 \mathrm{a}, \mathrm{b}$ and $7 \mathrm{c}$ ). The rise of $\mathrm{AR} \mathrm{CaCO}_{3}$ in the BT core $c a$. 12.2 kyr BP occurred together with the transition from inorganic-rich laminated sediments to sediments with laminations of dark-brown/beige laminae without bioturbation as well as the presence of macroscopic iron sulfide concretions and high Fe and Mn content. (Suppl. Fig. S7b).

During the mid-Holocene, $\mathrm{AR} \mathrm{CaCO}_{3}$ of $\mathrm{CHU}$ record decreases from $100 \pm 9$ to $59 \pm 2 \mathrm{~kg} \mathrm{~m}^{-2} \mathrm{kyr}^{-1}$, while BT and BC cores are characterized

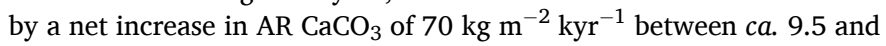

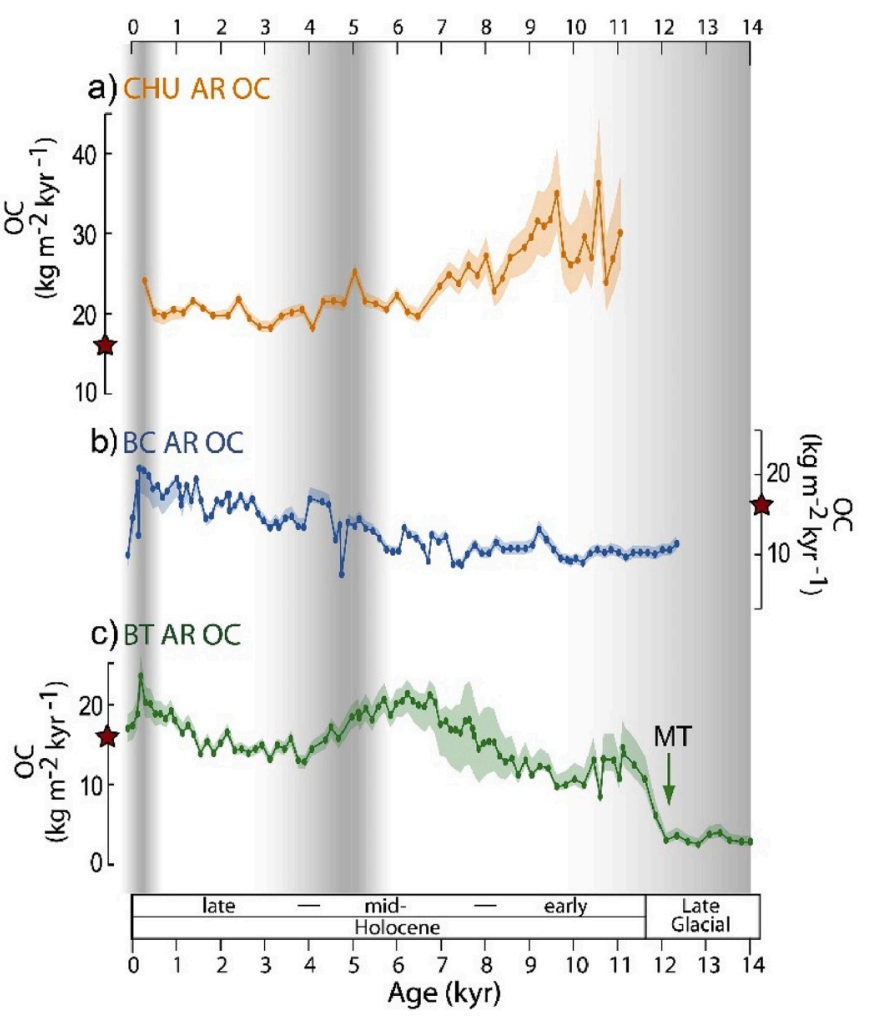

Fig. 5. Accumulation rates of organic carbon in the studied cores. Shaded areas indicate $95 \%$ confidence interval. Red stars in vertical axes indicate the presentday mean value of AR OC in Patagonian fjords after Smith et al. (2015). a) CHU, b) BC and c) BT. Green arrow indicates the marine transgression (MT) in this record. Vertical shaded areas denote cold periods (Late Glacial, beginning of Neoglacial period and the LIA, Kilian and Lamy, 2012). (For interpretation of the references to colour in this figure legend, the reader is referred to the Web version of this article.)

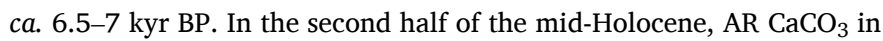
$\mathrm{BC}$ decreases in similar magnitude as BT, but increases abruptly between 5.5 and $5.3 \mathrm{kyr}$ BP followed by an increment in N/C ratios (Fig. 6a) and $\mathrm{Br}$ contents, which are reflected in the rise of $\mathrm{AR} \mathrm{OC}$ aq (Fig. $7 \mathrm{~d}$ and e). Thereafter, the three records show an overall decrease of $\mathrm{AR} \mathrm{CaCO}_{3}$, which reached a minimum before $0.3 \mathrm{kyr} B P$. The $\mathrm{AR} \mathrm{OC}$ aq in BT record rise gradually until ca. $6.5 \mathrm{kyr} \mathrm{BP}$ and decrease slightly after $c a .5 .5 \mathrm{kyr}$ BP (Fig. 7f).

\section{Discussion}

\subsection{Holocene sedimentation rates}

Sedimentation rates (SR) in fjord basins depend on the supply of siliciclastic components, allochthonous $\mathrm{OC}_{\text {terr }}$ from local catchment areas and local productivity within the water column (Cui et al., 2016; Bertrand et al., 2012, 2014; Harada et al., 2013; Lamy et al., 2010; Rebolledo et al., 2015, 2019). Moreover, open fjord systems may also receive a long-distance terrestrial sediment supply $(>100 \mathrm{~km})$, often depending on wind-induced surface currents or freshwater runoff within the fjord water surface layer. In particular, glacier sediment discharges can provide extended clay plumes as a major source of allochthonous siliciclastic input (Breuer et al., 2013a; Kilian et al., 2017). Regional and inter-basin variability in Holocene SR at the three sites investigated here suggest that long-distance sediment transport into small enclosed basins either plays no significant role or varies from basin to basin.

The relative contribution of terrestrial and aquatic sediment components depends on tidal, climatic and morphological characteristics of the fjords (Hinojosa et al., 2014). In particular, both the relationship of 


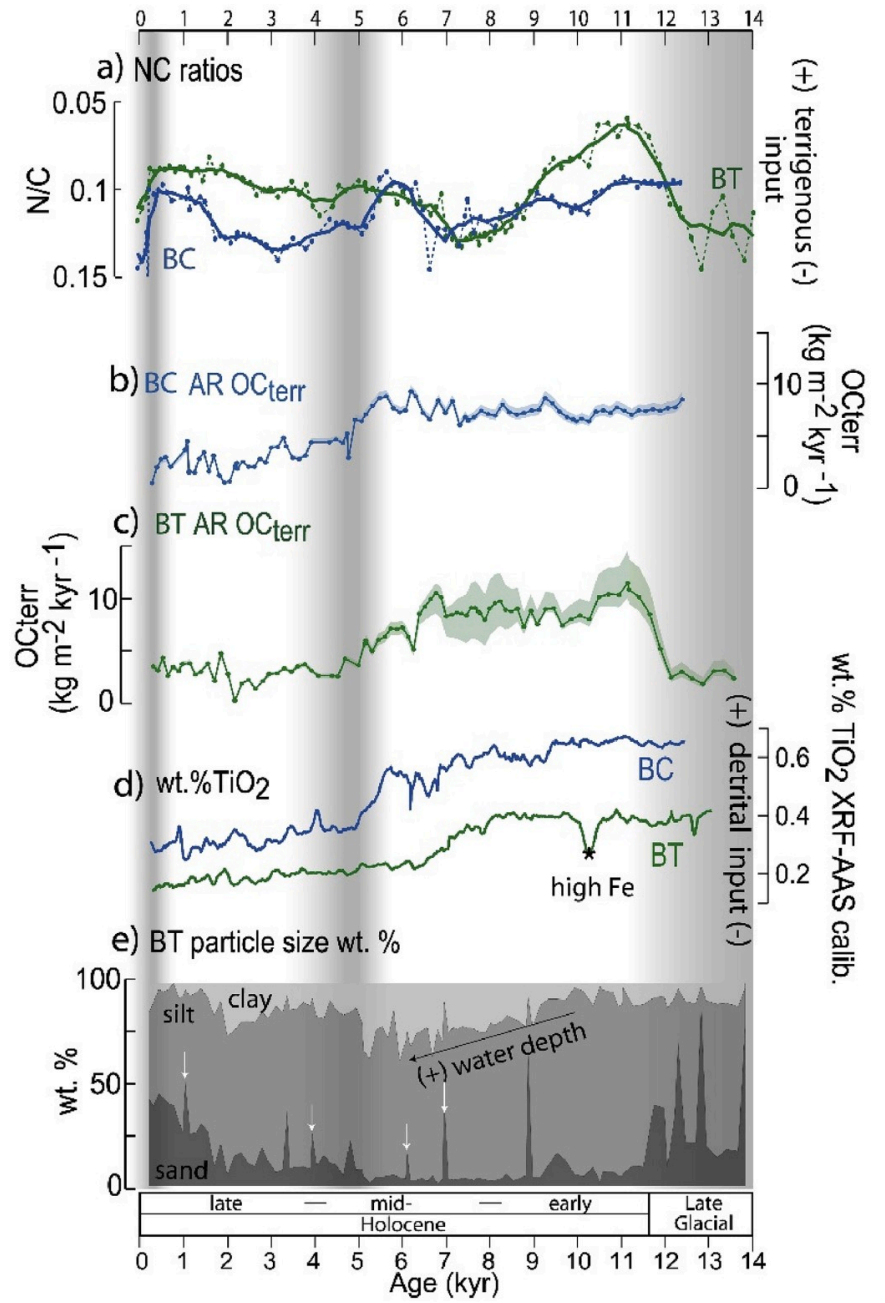

Fig. 6. Proxies of terrigenous input to the study sites. a) N/C ratios of BC and BT cores. Note the inverted scale. b) Accumulation rates of terrestrial carbon in core BC. c) Accumulation rates of terrestrial carbon in core BT. d) AAS calibrated XRF scanner of the matrix corrected Ti cps expressed as $\mathrm{wt} \%$ of $\mathrm{TiO}_{2}$ in $\mathrm{BC}$ and BT cores. The star indicates high Fe content in BT sediments (Suppl. Fig. S7b). e) Particle size distribution in BT core. White arrows indicate extreme depositional events. Vertical shaded areas denote cold periods (Late Glacial, beginning of Neoglacial period and LIA, Kilian and Lamy, 2012).

local and/or regional catchments and the areal extent of related basins affect sedimentation and individual accumulation rates of the distinct components (Cui et al., 2017; Smeaton and Austin, 2017; Smeaton et al., 2017). Fjord basins within well definable catchments, as used in this study, have the advantage that past changes in land surface properties (soil and plant development) as well as Holocene coastline evolution can be better constrained.

One of the previous studies on Holocene sediments from the Pacific side of the Magellan fjord region comes from a $560 \mathrm{~m}$ deep site near Cape Pilar (core PC-03; Harada et al., 2013, Fig. 1b). This core is mainly composed of siliciclastic allochthonous sediments and is characterized by high early Holocene SR, but very low SR during the Neoglacial after $5.5 \mathrm{kyr}$ BP. Higher values in the early Holocene have also been reported from shallow bays ( $<100 \mathrm{~m}$ WD; TM1, Palm2 and Par1; Fig. 1b) within the fjord system of the western Strait of Magellan (Kilian et al., 2007b; Lamy et al., 2010).

Among the newly investigated sediment cores, only the CHU record shows significantly higher early Holocene SR compared to the late Holocene, whereas the sediment cores BT and BC, located $\sim 100 \mathrm{~km}$ northnorthwest of $\mathrm{CHU}$ and closer to the Pacific coast, show a general subtle

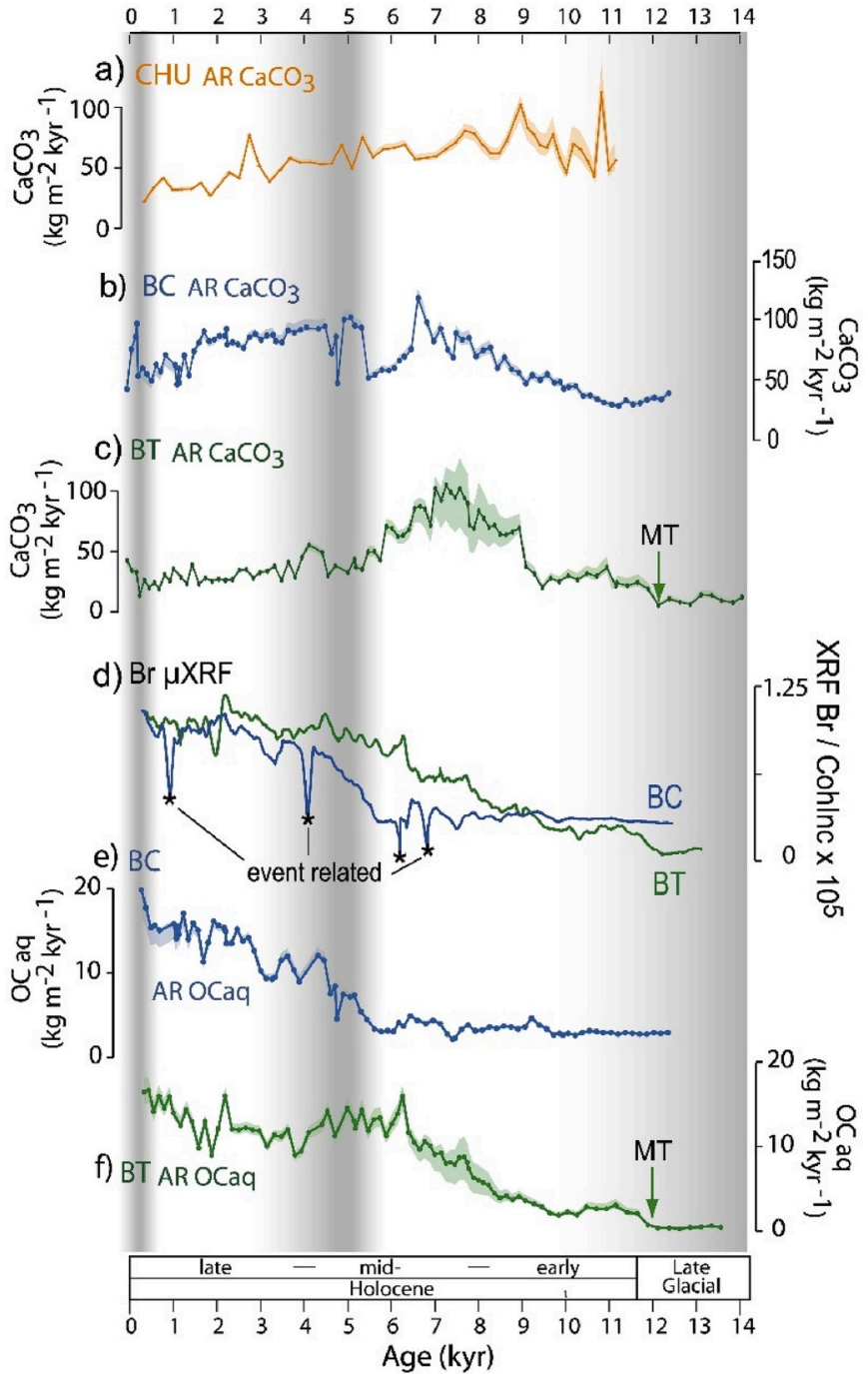

Fig. 7. Proxies of aquatic productivity at the studied sites. a), b), and c) Accumulation rates (AR) of $\mathrm{CaCO}_{3}$ in $\mathrm{CHU}$, BC and BT cores, respectively. d) Matrix-corrected XRF Br cps of BC and BT cores. Black stars indicate low values related to single depositional events in $\mathrm{BC}$ core. e) Accumulation rates of aquatic organic carbon $\left(\mathrm{OC}_{\mathrm{aq}}\right)$ of $\mathrm{BC}$ and $\mathrm{f}$ ) of $\mathrm{BT}$ records. $\mathrm{MT}=$ marine transgression. Vertical shaded areas denote cold periods (Late Glacial, beginning of Neoglacial period and LIA, Kilian and Lamy, 2012).

increase in SR throughout the Holocene. Relatively higher SR between 8 and $7 \mathrm{kyr}$ BP in the BT record might be related to the deepening of the basin due to the ongoing marine transgression (MT). The shallower sill at this site probably causes a higher sensitivity of the sedimentation dynamics to sea-level changes compared to the other two sites.

Since the glacial retreat in the western Strait of Magellan occurred before ca. $16 \mathrm{kyr}$ (Kilian et al., 2007b), we suggest that the generally higher early Holocene SR observed at many sites (TM1, PAR1, PC-03, Palm2 and CHU; Fig. 1b) may be attributed to a strong input of siliciclastic material and $\mathrm{OC}_{\text {terr }}$ from the surrounding land areas due to extremely high early Holocene precipitation rates (Lamy et al., 2010, Fig. 5d-h) as well as associated outwash of unconsolidated glacial detritus deposited during the Late Glacial (Breuer et al., 2013a). A possible explanation for the comparatively lower early Holocene SR at $\mathrm{BC}$ and $\mathrm{BT}$ sites is that the coastal area, apart from the ice caps in the inner fjords, may have had less availability of unconsolidated glacial material and less variable precipitation rates between early and late Holocene. Since there is less correlation between wind strength and precipitation in the borders of the SWW and towards the open Pacific 
(Garreaud et al., 2013), changes in strength, width and position of the SWW zone might have less impact on the precipitation rates in this coastal area, which could have hyper-humid climatic conditions during the whole Holocene.

\section{2. $O C_{\text {terr }}$ supply and vegetation development}

The N/C-Ti-Br based mass calculation indicate that the contribution of $\mathrm{OC}_{\text {terr }}$ to the overall $\mathrm{OC}$ range is between 20 and $80 \mathrm{wt} \%$ at the $\mathrm{BC}$ and $\mathrm{BT}$, with higher values during the early and mid-Holocene compared to the late Holocene. The supply of $\mathrm{OC}_{\text {terr }}$ depends on the relationship between the areas of vegetation-covered catchment and the sediment basin (Smeaton and Austin, 2017). Additionally, changes in precipitation and runoff may also influence the amount of $\mathrm{OC}_{\text {terr }}$ transported and deposited into fjord and lake basins, partly also during sudden depositional events triggered by earthquakes, volcanic eruptions or extreme precipitation events (Lamy et al., 2010).

In the Magellan region, the terrestrial organic matter supply to lakes and fjord basins started after the Late Glacial ice retreat (Kilian and Lamy, 2012). Pollen records from a lake sediment core of Tamar Island (Fig. 1b) indicate a primary plant succession starting after $\sim 15.5 \mathrm{kyr} B P$, when glaciers retreated towards the Gran Campo Nevado ice cap located $60 \mathrm{~km}$ further east and the establishment of a dense forest vegetation after 12 kyr BP (Lamy et al., 2010; Kilian et al., 2007b). The amount of pollen from peat-forming plant communities generally increased throughout the Holocene. Besides climate forcing, this can be partly related to long-term plant succession due to soil development and increasing soil thickness (Biester et al., 2003; Lamy et al., 2010; Yu et al., 2010). Next to Tamar Island, a 3 to 5 -fold higher AR OC terr during the early Holocene (compared to the mid- and late Holocene) in fjord cores TM1 and Palm2 has been interpreted as reflecting stronger SWW and higher precipitation that significantly increased the OC transport from terrestrial to aquatic systems (Lamy et al., 2010). This interpretation can be extrapolated to our CHU site, which is characterized by very high AR OC and low N/C ratios during the early Holocene (Fig. 5b). Further evidence for more humid conditions and stronger terrestrial input, and probably a more brackish environment during the early Holocene in Churruca fjord comes from high contributions of freshwater diatoms and the occurrence of chrysophyte cysts (C. Lange, unpublished data). Moreover, the OC input from terrestrial sources could have been enhanced at the CHU site by the transport from the nearby shallow Brazo León, which turned into a fluvial system as an additional catchment area during times of sea level low stand (Fig. 2a).

\subsection{Marine transgression and its effect on water column structure and paleoproductivity}

The Late Glacial to Holocene eustatic sea level rise (120 m; Lambeck et al., 2014, Fig. 8a) has significantly controlled the coastline evolution globally. In previously glaciated regions eustatic effects are partly superimposed by e.g. isostatic movements. Moreover, in tectonically active region like the Strait of Magellan, vertical movement in the order of several meters, could also have added to the eustatic and isostatic effects (Bentley and McCulloch, 2005; Breuer et al., 2013b; De Muro et al., 2018). Although the referenced studies provide some elements of the evolution of the coastline in the western Magellan fjord system and formation of terraces since the LGM, their influence on the aquatic environments in terms of development of e.g. stratified/mixed water columns and local sedimentary systems have not been considered.

The investigated bays and fjord have sills at different water depths, which may have controlled the timing of the MT and the influence from open Pacific waters, depending on the isostatic uplift rates. Based on the first occurrence of foraminifera and the increase in $\mathrm{AR} \mathrm{CaCO}_{3}$ in a coastal sediment core next to Tamar Island (TM1, Fig. 1b), Kilian et al. (2007a) suggested a first significant MT in the western Strait of Magellan at $14.3 \mathrm{kyr}$ BP. This was probably related to the rapid sea-level rise a)

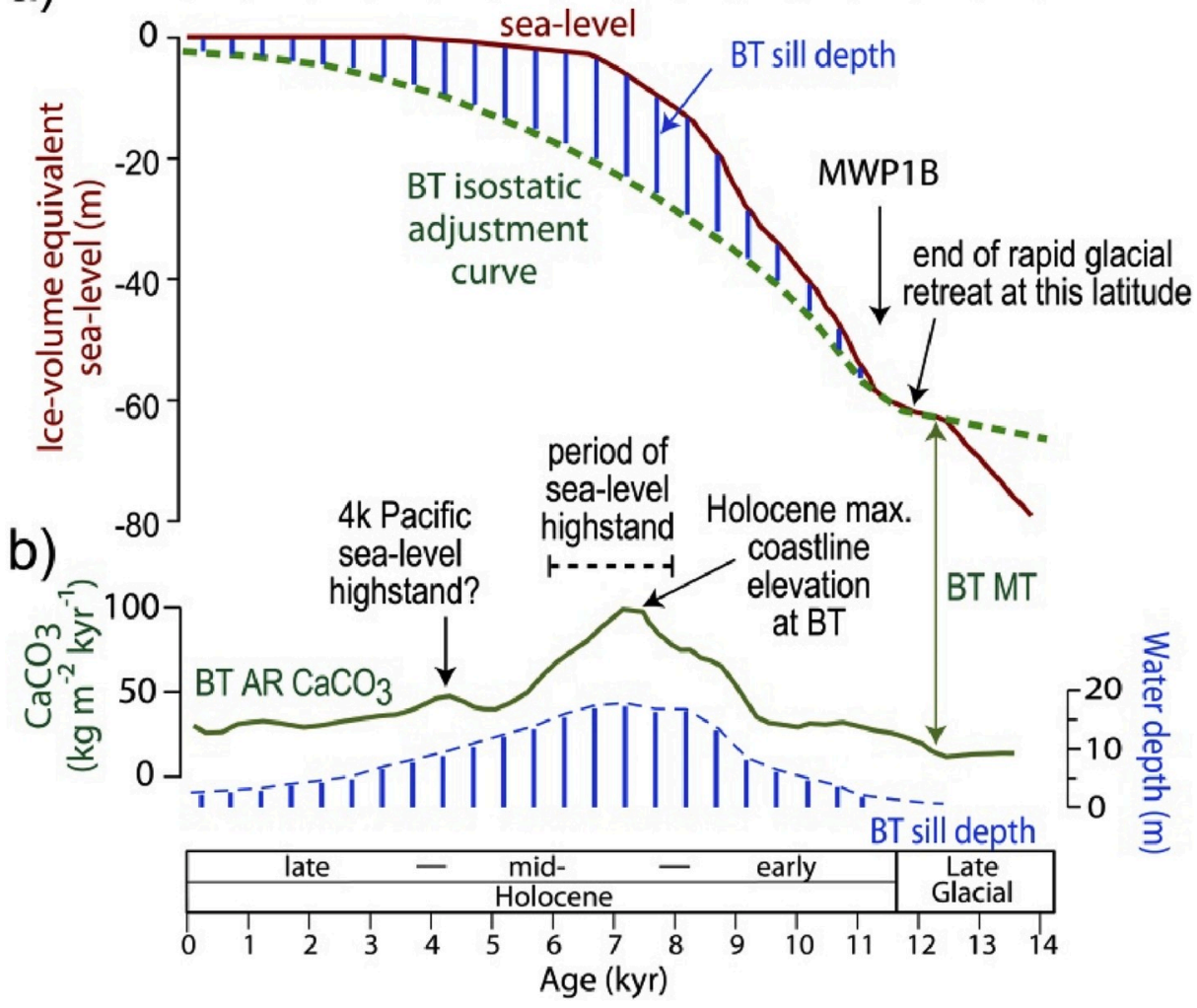

Fig. 8. a) Global sea level rise (red line; Lambeck et al., 2014) and the hypothetical isostatic adjustment curve at BT site. Depth changes at the basin entrance are indicated with vertical blue lines. MWP1B: Meltwater pulse 1B. Glacial retreat timing from Kilian and Lamy (2012). b) $\mathrm{CaCO}_{3}$ accumulation rates at BT site shown with 4 points moving average smoothed curve. Length of vertical blue lines refer to changes in water depths at this site sill. Sea-level highstands of records from the Pacific Ocean (Chiba et al., 2016; Clement et al., 2016; Miklavič et al., 2018; Yokoyama et al., 2016). (For interpretation of the references to colour in this figure legend, the reader is referred to the Web version of this article.) 
during meltwater pulse $1 \mathrm{~A}$ from -120 to $-80 \mathrm{~m}$ (Lambeck et al., 2014). The bay of the BC site has at present a deeper sill (15 m WD) and already shows marine conditions at the base of the record at $13 \mathrm{kyr}$ BP, while the shallower-sill site BT documents the MT at ca. $12.2 \mathrm{kyr}$ BP. This suggests that the MT in both BT and BC sites occurred when the global sea level was $60-70 \mathrm{~m}$ lower than at present; therefore the Pacific coastline was isostatically depressed by a similar degree at this time (Fig. 8). The preservation of OC-rich laminae in the BT record between ca. 12.2 and 10.4 kyr BP suggests anoxic conditions at the sediment-water interface during this period. The halocline likely established around 12.2 when the marine water started to enter the basin, while the precipitation rates were high (Lamy et al., 2010). The start of brackish conditions in BT is indicated by the increase of $\mathrm{AR}$ of $\mathrm{CaCO}_{3}$ and $\mathrm{OC}_{\mathrm{aq}}$ and XRF $\mathrm{Br}$ content (Fig. 7). After ca. $11.7 \mathrm{kyr} \mathrm{BP}$, peaks of $\mathrm{Fe}$ and $\mathrm{Mn} / \mathrm{Ti}$ associated with laminations might be related with alternating sulfidic and oxic water masses since the onset of the MT (Sternbeck and Sohlenius, 1997). The progressive deepening of the BT sill during the early and mid-Holocene has probably resulted in more mixing in the water column. Further establishment of oxic condition in the sediment-water interface is indicated by remnants of marine organisms (Chlamys sp. and Desmophyllum sp.; Fig. 9).

Records from the central basin of the Strait of Magellan indicate the increment of aquatic productivity after the MT through the Atlantic entrance (cores JPC67, Bertrand et al., 2017, and MD07/3132, Aracena et al., 2015). In both BT and BC cores from the Pacific coast, $\mathrm{AR} \mathrm{CaCO}_{3}$ increased slightly during the early Holocene and reached a maximum between $c a$. 6.5 and $7 \mathrm{kyr}$ BP (Fig. $7 \mathrm{~b}$ and c). This could be explained by maximum sill depths at this time and a highest coastline elevation. As illustrated in Fig. 8, we suggest that the rates of eustatic rise were higher than the isostatic uplift rates causing a deepening of the sills and increased sea water intrusion into the bays reaching a maximum around 7 kyr BP. Afterwards, the eustatic sea-level stabilized on a global scale, while the local isostatic uplift may have continued slightly. This again could have caused shallower sills at the BT and BC sites reducing the marine influence in the second half of the Holocene. This is e.g., indi-

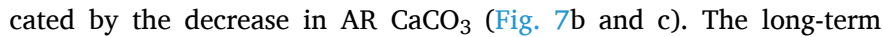
decrease of $\mathrm{AR} \mathrm{CaCO}_{3}$ since ca. 7 kyr BP could have been related in general to paleoproductivity changes due to Neoglacial glacier advances and related cold melt water discharge, a reduced degree of MT as discussed above or phases of precipitation-related surface water freshening. The higher sensibility to sea-level changes at BT site might be indicated by the increase in $\mathrm{AR} \mathrm{CaCO}_{3}$ around $4 \mathrm{kyr} \mathrm{BP}$, which could be related with the sea-level highstand documented in other areas of the Pacific Ocean (Fig. 8; Chiba et al., 2016; Clement et al., 2016; Miklavič et al., 2018; Yokoyama et al., 2016).

Holocene variations in the relative abundance of carbon from different sources in fjord sediments respond to changes in oceanography and sea-level (Knies, 2005; Moossen et al., 2013). At the studied sites, $\mathrm{AR} \mathrm{CaCO}_{3}$ are affected by the enhanced input of marine nutrients by an increasing degree of MT, which is a plausible explanation for the increment in productivity. Cuevas et al. (2019) report that chlorophyll-a concentration within the water column is favored by oceanic nutrients in southern Patagonia. Carbonate producer organisms, in particular benthic foraminifera (Pawłowska et al., 2017) have a range of $\mathrm{pH}$ tolerance that varies from species to species. Laboratory culture experiments indicate that salinity induced $\mathrm{pH}$ changes affect calcification and reproduction in benthic foraminifera. The response to salinity changes is not linear, but with salinities $<20$ psu the reproduction rate is $<3 \%$ and salinities $<10$ psu cause the death of specimens preceded by dissolution of the entire test (Saraswat et al., 2011).

Overall accumulation rates of $\mathrm{OC}$ in $\mathrm{BC}$ and $\mathrm{BT}$ are lower than in the CHU record, but still in the same order of magnitude. Our estimates range between 7.5 and $36.2 \mathrm{~g} \mathrm{~m}^{-2} \mathrm{y}^{-1}$, which are comparable with values published from Scotland (3.0-32.1 $\mathrm{g} \mathrm{m}^{-2} \mathrm{y}^{-1}$; Smeaton et al., 2016) and

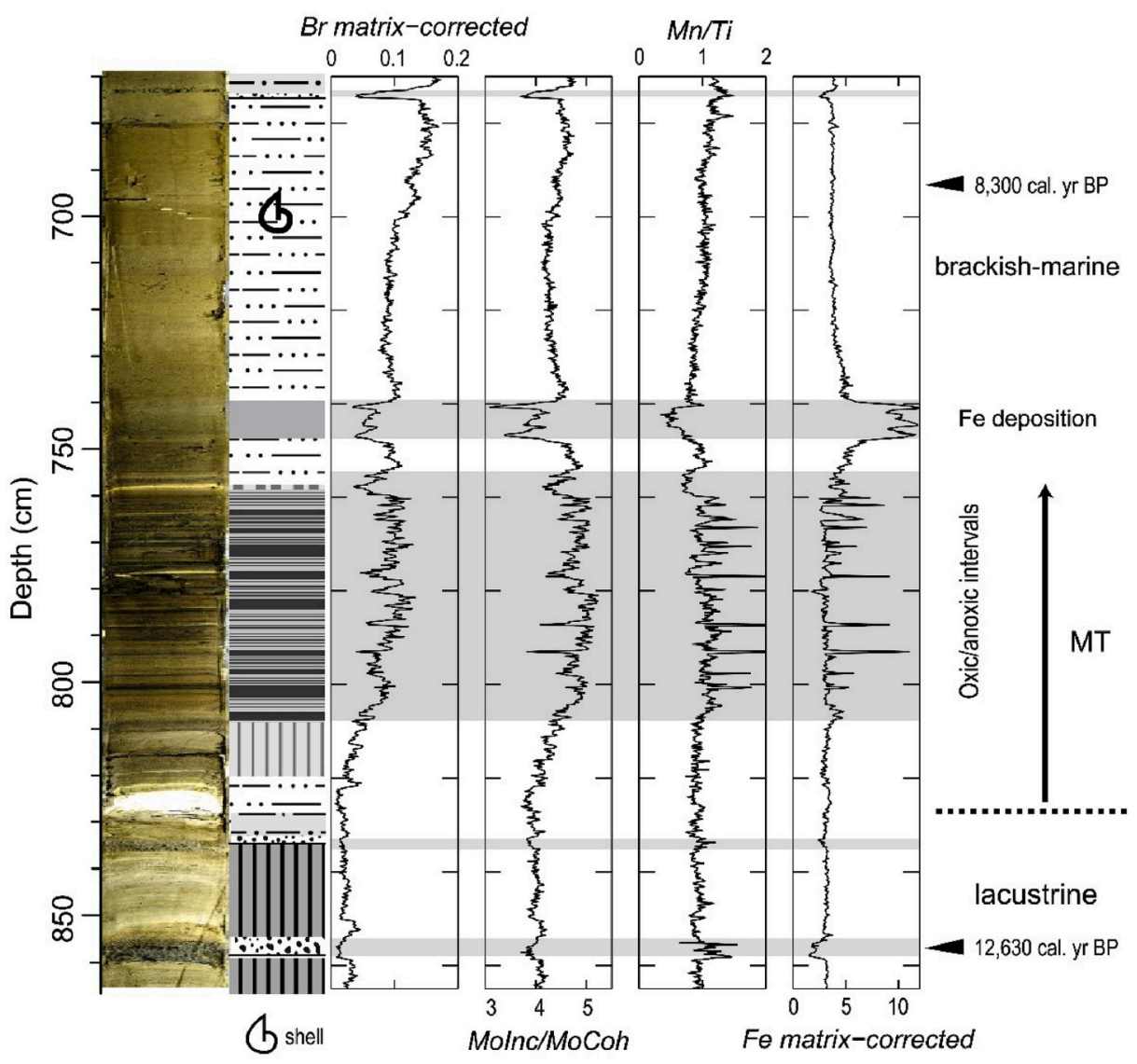

Fig. 9. Marine transgression in BT record. Photographic mosaic, core description (Suppl. Fig. S4), and XRF proxies (see section 5.3). 
European Artic Fjords (20.3-40.5 $\mathrm{g} \mathrm{m}^{-2} \mathrm{yr}^{-1}$; Koziorowska et al., 2018). Other fjord regions present mean values that are in a similar range, but the upper values are half to one order of magnitude higher than our estimations, e.g., Northern Patagonia (1.9-82.5 $\mathrm{g} \mathrm{m}^{-2} \mathrm{y}^{-1}$; Sepúlveda et al., 2011), New Zealand (9.1-68.0 $\mathrm{g} \mathrm{m}^{-2} \mathrm{y}^{-1}$; Cui et al., 2016; Hinojosa et al., 2014; Knudson et al., 2011; Smith et al., 2015), Norway (13-171 $\mathrm{g} \mathrm{m}^{-2} \mathrm{yr}^{-1}$; Duffield et al., 2017; Faust and Knies, 2018) and Canada (20-290 $\mathrm{g} \mathrm{m}^{-2} \mathrm{yr}^{-1}$; St-Onge and Hillaire-Marcel, 2001). These values should reflect the spatial heterogeneity of AR OC between fjord systems, which has been linked with the sediment type and particle size of the seabed (Smeaton and Austin, 2019).

\section{Conclusions}

Three new sediment records from shallow coastal bays and fjords from the western sector of the Strait of Magellan fjord area were used to investigate environmental variability, organic fluxes and carbon accumulation throughout the Holocene.

Despite the relative proximity of the sites, we observe distinct dynamics of terrestrial carbon accumulation in the three sediment records. These differences are mainly caused by geomorphological factors. Site $\mathrm{CHU}$ can be considered as an inner fjord environment with a welldeveloped soil and vegetation catchment. Sites BT and BC represent more open coastal basins, the first with vegetation and soil cover and the second with very restricted terrestrial organic sources.

The coastal sites present comparatively more constant SR throughout the whole Holocene, whereas the inner fjord has significantly higher and more variable early Holocene SR for two possible reasons: 1) coastal sites have less variation in precipitation between early and late Holocene, and 2) the amount of clastic glacial sediments was much higher in the inner fjords proximal to the large glacier systems, while the coastal ice-distal areas provide a reduced stock of glacial sediment supply during the early Holocene. In addition, our results indicate that AR $\mathrm{OC}_{\text {terr }}$ in coastal areas are particularly sensitive to local parameters, such as catchment/basin area ratio, plant succession and precipitation regime.

The results demonstrate that the $\mathrm{AR} \mathrm{CaCO}_{3}$ and $\mathrm{AR} \mathrm{OC}_{\mathrm{aq}}$ are indicative of water column structure in particular for the supply of ocean water and the effect of surface water freshening. The timing and magnitude of the marine transition is controlled by the specific sill depths at each site. Between $\mathrm{BT}$ and $\mathrm{BC}$ records, the sill-depth difference is $12 \mathrm{~m}$. The $\mathrm{BC}$ record shows marine conditions at least since $c a .13 \mathrm{kyr}$

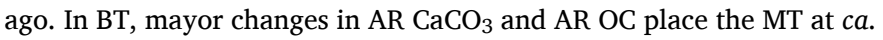
12.2 kyr BP, when the global sea level was 60-70 m lower than today. This implies an isostatic rebound of this magnitude for the area just to the north of the Strait of Magellan entrance. The interaction between sea level and isostatic adjustment during the Holocene plays a major role for the paleoproductivity changes at coastal sites in western Patagonia.

\section{Acknowledgements}

We would like to thank three anonymous reviewers for their comments on this paper and helpful suggestions for improvements. This study was funded by project number 111083487 (Ki-456/12) and (Ki456-/9-1) by the German Research Society (Deutsche Forschungsgemeinschaft: DFG). C.B. Lange acknowledges partial support from Chilean grants CONICYT AFB 170006, and CONICYT FONDAP 150100007 and 15150003. We acknowledge logistic and technical support given by Marcelo Arévalo, Carlos Ríos and Erika Mutschke (UMAG, Punta Arenas, Chile).

To the memory of Prof. Dr. Rolf Kilian for his indefatigable efforts and huge contribution to the knowledge of the Patagonian fjords system.

\section{Appendix A. Supplementary data}

Supplementary data to this article can be found online at https://doi. $\operatorname{org} / 10.1016 / j . c s r .2020 .104101$.

\section{References}

Aracena, C., Lange, C.B., Iriarte, J.L., Rebolledo, L., Pantoja, S., 2011. Latitudinal patterns of export production recorded in surface sediments of the Chilean Patagonian fjords $\left(41^{\circ}-55^{\circ} \mathrm{S}\right)$ as a response to water column productivity. Continent. Shelf Res. 31 (3-4), 340-355. https://doi.org/10.1016/j.csr.2010.08.008.

Aracena, C., Kilian, R., Lange, C.B., Bertrand, S., Lamy, F., Arz, H.W., De Pol-Holz, R., Baeza, O., Pantoja, S., Kissel, C., 2015. Holocene variations in productivity associated with changes in glacier activity and freshwater flux in the central basin of the Strait of Magellan. Palaeogeogr. Palaeoclimatol. Palaeoecol. 436, 112-122. https://doi.org/10.1016/j.palaeo.2015.06.023.

Bentley, M., McCulloch, R., 2005. Impact of neotectonics on the record of glacier and sea level fluctuations, Strait of Magellan, Southern Chile. Geogr. Ann. 87 (A), 393-402. https://doi.org/10.1111/j.0435-3676.2005.00265.x.

Bertrand, S., Hughen, K.A., Sepúlveda, J., Pantoja, S., 2012. Geochemistry of surface sediments from the fjords of Northern Chilean Patagonia (44-47 ${ }^{\circ}$ ): spatial variability and implications for paleoclimate reconstructions. Geochem. Cosmochim. Acta 76, 125-146. https://doi.org/10.1016/j.gca.2011.10.028.

Bertrand, S., Hughen, K.A., Sepúlveda, J., Pantoja, S., 2014. Late Holocene covariability of the southern westerlies and sea surface temperature in northern Chilean Patagonia. Quat. Sci. Rev. 105, 195-208. https://doi.org/10.1016/j. quascirev.2014.09.021.

Bertrand, S., Lange, C.B., Pantoja, S., Hughen, K., van Tornhout, E.V., Wellner, J.S., 2017. Postglacial fluctuations of Cordillera Darwin glaciers (southernmost Patagonia) reconstructed from Almirantazgo fjord sediments. Quat. Sci. Rev. 177, 265-275. https://doi.org/10.1016/j.quascirev.2017.10.029.

Bianchi, T.S., Arndt, S., Austin, W.E.N., Benn, D.I., Bertrand, S., Cui, X., Faust, J.C., Koziorowska-Makuch, K., Moy, C.M., Savage, C., Smeaton, C., Smith, R., Syvitski, J., 2020. Fjords as aquatic critical zones (ACZs). Earth Sci. Rev. https://doi.org/ 10.1016/j.earscirev.2020.103145 (in press).

Biester, H., Martinez-Cortizas, A., Birkenstock, S., Kilian, R., 2003. The effect of peat decomposition, and mass loss on historic mercury records in peat bogs from Patagonia. Envrion. Sci. Technol. 37, 32-39. https://doi.org/10.1021/es025657u.

Blaauw, M., 2010. Methods and code for 'classical' age-modelling of radiocarbon sequences. Quat. Geochronol. 5, 512-518. https://doi.org/10.1016/j. quageo.2010.01.002.

Boyer, T.P., Antonov, J.I., Baranova, O.K., Coleman, C., Garcia, H.E., Grodsky, A., Johnson, D.R., Locarnini, R.A., Mishonov, A.V., O'Brien, T.D., Paver, C.R., Reagan, J. R., Seidov, D., Smolyar, I.V., Zweng, M.M., 2013. World ocean database 2013. In: Levitus, S., Mishonov, A. (Eds.), NOAA Atlas NESDIS 72, Technical Ed. Silver Spring, MD. https://doi.org/10.7289/V5NZ85MT. 209 pp.

Breuer, S., Kilian, R., Baeza, O., Lamy, F., Arz, H., 2013a. Holocene denudation rates from the superhumid southernmost Chilean Patagonian Andes $\left(53^{\circ} \mathrm{S}\right)$ deduced from lake sediment budgets. Geomorphology 164 (2), 135-152. https://doi.org/10.1016/ j.geomorph.2013.01.009.

Breuer, S., Kilian, R., Schörner, D., Weinrebe, W., Behrmann, J., Baeza, O., 2013b. Glacial and tectonic control on fjord morphology and sediment deposition in the Magellan region (53 ${ }^{\circ}$ ), Chile. Mar. Geol. 346, 31-46. https://doi.org/10.1016/j. margeo.2013.07.015.

Chague-Goff, C., Chan, J.C.H., Goff, J., Gadd, P., 2016. Late Holocene record of environmental changes, cyclones and tsunamis in a coastal lake, Mangaia, Cook Islands. Isl. Arc 25, 333-349. https://doi.org/10.1111/iar.12153.

Chawchai, S., Kylander, M.E., Chabangborn, A., Löwemark, L., Wohlfarth, B., 2016. Testing commonly used X-ray fluorescence core scanning based proxies for organicrich lake sediments and peat. Boreas 45, 180-189. https://doi.org/10.1111/ bor. 12145 .

Chiba, T., Sugihara, S., Matsushima, Y., Arai, Y., Endo, K., 2016. Reconstruction of Holocene relative sea-level change and residual uplift in the lake Inba area, Japan. Palaeogeogr. Palaeoclimatol. Palaeoecol. 441, 982-996. https://doi.org/10.1016/j. palaeo.2015.10.042.

Clement, A.J.H., Whitehouse, P.L., Sloss, C.R., 2016. An examination of spatial variability in the timing and magnitude of Holocene relative sea-level changes in the New Zealand archipelago. Quat. Sci. Rev. 131, 73-101. https://doi.org/10.1016/j. quascirev.2015.09.025.

Croudace, I.W., Rindby, A., Rothwell, R.G., 2006. ITRAX: description and evaluation of a new multi-function X-ray core scanner. In: Geological Society, London, Special Publications, 267, pp. 51-63. https://doi.org/10.1144/GSL.SP.2006.267.01.04, 1.

Cuevas, L.A., Tapia, F.J., Iriarte, J.L., González, H.E., Silva, N., Vargas, C.A., 2019. Interplay between freshwater discharge and oceanic waters modulates phytoplankton size-structure in fjords and channel systems of the Chilean Patagonia. Prog. Oceanogr. 173, 103-113. https://doi.org/10.1016/j.pocean.2019.02.012.

Cui, X.Q., Bianchi, T.S., Savage, C., Smith, R.W., 2016. Organic carbon burial in fjords: terrestrial versus marine inputs. Earth Planet Sci. Lett. 451, 41-50. https://doi.org/ 10.1016/j.epsl.2016.07.003.

Cui, X.Q., Bianchi, T.S., Savage, C., 2017. Erosion of modern terrestrial organic matter as a major component of sediments in fjords. Geophys. Res. Lett. 44, 1457-1465. https://doi.org/10.1002/2016GL072260.

Davies, S.J., Lamb, H.F., Roberts, S.J., 2015. Micro-XRF core scanning in palaeolimnology: recent developments. In: Croudace, I.W., Rothwell, R.G. (Eds.), Micro-XRF Studies of Sediment Cores: Applications of a Non-destructive Tool for the Environmental Sciences, 17. Springer, pp. 189-226. https://doi.org/10.1007/97894-017-9849-5. Developments in Paleoenvironmental Research. 
De Muro, S., Tecchiato, S., Porta, M., Buosi, C., Ibba, A., 2018. Geomorphology of marine and glacio-lacustrine terraces and raised shorelines in the northern sector of Península Brunswick, Patagonia, Straits of Magellan, Chile. J. Maps 14 (2), 135-143. https://doi.org/10.1080/17445647.2018.1441759.

Diaz-Michelena, M., Kilian, R., 2015. Magnetic signatures of the orogenic crust of the Patagonian Andes with implication for planetary exploration. Phys. Earth Planet. In 248, 35-54. https://doi.org/10.1016/j.pepi.2015.08.005.

Duffield, C., Alve, E., Andersen, N., Andersen, T., Hess, S., Strohmeier, T., 2017. Spatial and temporal organic carbon burial along a fjord to coast transect: a case study from Western Norway. Holocene 27, 1325-1339. https://doi.org/10.1177/ 0959683617690588.

Faust, J.C., Knies, J., 2019. Organic matter sources in north atlantic fjord sediments. Gcubed 20 (6), 2872-2885. https://doi.org/10.1029/2019GC008382.

Fernandes, R., Millard, A.R., Brabec, M., Nadeau, M.J., Grootes, P., 2014. Food reconstruction using isotopic transferred signals (FRUITS): a Bayesian model for diet reconstruction. PloS One 9 (2), 1-9. https://doi.org/10.1371/journal. pone. 0087436 .

Fletcher, M.S., Moreno, P.I., 2012. Have the Southern Westerlies changed in a zonally symmetric manner over the last 14,000 years? A hemisphere-wide take on a controversial problem. Quat. Int. 276, 299-299. https://doi:10.1016/j.quaint.20 11.04.042.

Frank, D., Reichstein, M., Bahn, M., Thonicke, K., Frank, D., Mahecha, M.D., Smith, P., Van Der Velde, M., Vicca, S., Babst, F., Beer, C., Buchmann, N., Canadell, J.G. Ciais, P., Cramer, W., Ibrom, A., Miglietta, F., Poulter, B., Ramming, A., Seneviratne, S.I., Walz, A., Wattenbach, M., Zavala, M.A., Zscheischler, J., 2015. Effects of climate extremes on the terrestrial carbon cycle: concepts, processes and potential future impacts. Global Change Biol. 21, 2861-2880. https://doi.org/ 10.1111/gcb.12916.

Garreaud, R., 2009. The Andes climate and weather. Adv. Geosci. 22, 3-11. https://doi. org/10.5194/adgeo-22-3-2009.

Garreaud, R., Lopez, P., Minvielle, M., Rojas, M., 2013. Large-scale control on the patagonian climate. J. Clim. 26 (1), 215-230. https://doi.org/10.1175/JCLI-D-12 00001.1 .

González, H.E., Castro, L.R., Daneri, G., Iriarte, J.L., Silva, N., Tapia, F., Teca, E., Vargas, C.A., 2013. Land-ocean gradient in haline stratification and its effects on plankton dynamics and trophic carbon fluxes in Chilean Patagonian fjords (47-50 S). Prog. Oceanogr. 119, 32-47. https://doi.org/10.1016/j. pocean.2013.06.003.

González, H.E., Nimptsch, J., Giesecke, R., Silva, N., 2019. Organic matter distribution, composition and its possible fate in the Chilean North-Patagonian estuarine system. Sci. Total Environ. 657, 1419-1431. https://doi.org/10.1016/j. scitotenv.2018.11.445.

Harada, N., Ninnemann, U., Lange, C.B., Marchant, M., Sato, M., Ahagon, N., Pantoja, S. 2013. Deglacial-holocene environmental changes at the pacific entrance of the Strait of magellan. Palaeogeogr. Palaeoclimatol. Palaeoecol. 375, 125-135. https://doi. org/10.1016/j.palaeo.2013.02.022.

Hinojosa, J.L., Moy, C.M., Stirling, C.H., Wilson, G.S., Eglinton, T.I., 2014. Carbon cycling and burial in New Zealand's fjords. G-cubed 15 (10), 4047-4063.

Hervé, F., Pankhurst, R.J., Fanning, C.M., Calderón, M., Yaxley, G.M., 2007. The South Patagonian batholith: 150 my of granite magmatism on a plate margin. Lithos 97 , 373-394. https://doi.org/10.1016/j.lithos.2007.01.007.

Hogg, A.G., Hua, Q., Blackwell, P.G., Niu, M., Buck, C.E., Guilderson, T.P., Heaton, T.J., Palmer, J.G., Reimer, P.J., Reimer, R.W., Turney, C.S.M., Zimmerman, S.R.H., 2013. SHCal13 southern hemisphere calibration, 0-50,000 years cal BP. Radiocarbon 55, 1889-1903. https://doi.org/10.2458/azu_js_rc.55.16783.

Hromic, T., Ishman, S.D., Silva, N., 2006. Benthic foraminiferal distributions in Chilean fjords: $47^{\circ} \mathrm{S}$ to $54^{\circ} \mathrm{S}$. Mar. Micropaleontol. 59, 115-134. https://doi.org/10.1016/j. marmicro.2006.02.001.

Iriarte, J.L., van Ardelan, M., Cuevas, L.A., González, H.E., Sánchez, N., Myklestad, S.M., 2014. Size-spectrum based differential response of phytoplankton to nutrient and iron-organic matter combinations in microcosm experiments in a Chilean Patagonian Fjord. Phycol. Res. 62, 136-146. https://doi.org/10.1111/pre.12050.

Kilian, R., Lamy, F., 2012. A review of Glacial and Holocene paleoclimate records from southernmost Patagonia (49-55 ${ }^{\circ}$ S). Quat. Sci. Rev. 53, 1-23. https://doi.org/ 10.1016/j.quascirev.2012.07.017.

Kilian, R., Hohner, H., Biester, H., Wallrabe-Adams, C., Stern, C., 2003. Holocene peat and lake sediment tephra record from the southernmost Andes (53-55 $\mathrm{S}$ ). Rev. Geol. Chile 30, 47-64. https://doi.org/10.5027/andgeoV30n1-a02.

Kilian, R., Biester, H., Behrmann, J., Baeza, O., Fesq-Martin, M., Hohner, M., Schimpf, D., Friedmann, A., Mangini, A., 2006. Millennium-scale volcanic impact on a superhumid and pristine ecosystem. Geology 34, 609-612. https://doi.org/10.1130/ G22605.1.

Kilian, R., Baeza, O., Steinke, T., Arevalo, M., Rios, C., Schneider, C., 2007a. Late Pleistocene to Holocene marine transgression and thermohaline control on sediment transport in the western Magellanes fjord system of Chile $\left(53^{\circ} \mathrm{S}\right)$. Quat. Int. 161, 90-107. https://doi.org/10.1016/j.quaint.2006.10.043.

Kilian, R., Schneider, C., Koch, J., Fesq-Martin, M., Biester, H., Casassa, G., Arévalo, M., Wendt, G., Baeza, O., Behrmann, J., 2007b. Palaeoecological constraints on late glacial and Holocene ice retreat in the southern Andes $\left(53^{\circ} \mathrm{S}\right)$. Global Planet. Change 59, 49-66. https://doi.org/10.1016/j.gloplacha.2006.11.034.

Kilian, R., Lamy, F., Arz, H., 2013a. Late Quaternary variations of the southern westerly wind belt and its influences on aquatic ecosystems and glacier extend within the southernmost Andes. Zeitschrift Der Deutschen Gesellschaft Fur Geowissenschaften 164, 279-294. https://doi.org/10.1127/1860-1804/2013/0027.

Kilian, R., Baeza-Urrea, O., Breuer, S., Ríos, F., Arz, H., Lamy, L., Wirtz, J., Baque, D., Korf, P., Kremer, K., Ríos, C., Mutschke, E., Simon, M., De Pol-Holz, R., Arevalo, M.,
Wörner, G., Schneider, C., Casassa, G., 2013b. Late glacial and Holocene paleogeopgraphical and paleoecological evolution of the seno skyring and otway fjord systems in the magellanes region. Anales Instituto Patagonia (Chile) 41 (2), 7-21. https://doi.org/10.4067/S0718-686X2013000200001.

Kilian, R., Breuer, S., Behrmann, J.H., Baeza, O., Diaz-Michelena, M., Mutschke, E., Arz, H.W., Lamy, F., 2017. The Seno Otway pockmark field and its relationship to thermogenic gas occurrence at the western margin of the Magallanes Basin (Chile). Geo Mar. Lett. 38 (3), 227-240. https://doi.org/10.1007/s00367-017-0530-6.

Knies, J., 2005. Climate-induced changes in sedimentary regimes for organic matter supply on the continental shelf off northern Norway. Geochem. Cosmochim. Acta 69 (19), 4631-4647. https://doi.org/10.1016/j.gca.2005.05.014.

Knudson, K.P., Hendy, I.L., Neil, H.L., 2011. Re-examining Southern Hemisphere westerly wind behavior: insights from a late Holocene precipitation reconstruction using New Zealand fjord sediments. Quat. Sci. Rev. 30 (21-22), 3124-3138. htt p://doi:10.1016/j.quascirev.2011.07.017.

Korup, O., Seidemann, J., Mohr, C.H., 2019. Increased landslide activity on forested hillslopes following two recent volcanic eruptions in Chile. Nat. Geosci. 12, 284-289. https://doi.org/10.1038/s41561-019-0315-9.

Koziorowska, K., Kuliński, K., Pempkowiak, J., 2018. Comparison of the burial rate estimation methods of organic and inorganic carbon and quantification of carbon burial in two high Arctic fjords. Oceanologia 60 (3), 405-418. https://doi.org/ 10.1016/j.oceano.2018.02.005.

Lambeck, K., Rouby, H., Purcell, A., Sun, Y., Sambridge, M., 2014. sea level and global ice volumes from the last glacial maximum to the Holocene. Proc. Natl. Acad. Sci. Unit. States Am. 111 (43), 15296-15303.

Lafon, L., Silva, N., Vargas, C.A., 2014. Contribution of allochthonous organic carbon across the Serrano River Basin and the adjacent fjord system in Southern Chilean Patagonia: insights from the combined use of stable isotopes and fatty acid markers. Prog. Oceanogr. 129, 98-113. https://doi.org/10.1016/j.pocean.2014.03.004.

Lamy, F., Kilian, R., Arz, H., Francois, J., Kaiser, J., Prange, M., Steinke, T., 2010. Holocene changes in the position and intensity of the southern westerly wind belt. Nat. Geosci. 3, 695-699. https://doi.org/10.1038/NGEO959.

Lamy, F., Arz, H.W., Kilian, R., Lange, C.B., Lembke-Jene, L., Wengler, M., Kaiser, J., Baeza-Urrea, O., Hall, I.R., Harada, N., Tiedemann, R., 2015. Glacial reduction and millennial-scale variations in Drake Passage throughflow. Proc. Natl. Acad. Sci. Unit. States Am. 112, 13496-13501. https://doi.org/10.1073/pnas.1509203112.

McCulloch, R.D., Bentley, M.J., Tipping, R.M., Clapperton, C.M., 2005. Evidence for lateglacial ice-dammed lakes in the central Strait of magellan and Bahia inutil, Southernmost South America. Geogr. Ann. 87 (A2), 335-362. https://doi.org/ 10.1111/j.0435-3676.2005.00262.x.

Miklavič, B., Yokoyama, Y., Urata, K., Miyairi, Y., Kan, H., 2018. Holocene relative sea level history from phreatic overgrowths on speleothems (POS) on Minami Daito Island, Northern Philippine Sea. Quat. Int. 417, 359-368. https://doi.org/10.1016/j. quaint.2017.09.032.

Milzer, G., Giraudeau, J., Faust, J., Knies, J., Eynau, F., Rühlemann, C., 2013. Spatial distribution of benthic foraminiferal stable isotopes and dinocyst assemblages in surface sediments of the Trondheimsfjord, central Norway. Biogeosciences 10, 1-16. https://doi.org/10.5194/bg-10-1-2013.

Mohr, C.H., Korup, O., Ulloa, H., Iroumé, A., 2017. Pyroclastic eruption boosts organic carbon fluxes into Patagonian fjords. Global Biogeochem. Cycles 31 (11), 1626-1638. https://doi.org/10.1002/2017GB005647.

Moossen, H., Abell, R., Quillmann, U., Bendle, J., 2013. Holocene changes in marine productivity and terrestrial organic carbon inputs into an Icelandic fjord: application of molecular and bulk organic proxies. Holocene 23 (12), 1699-1710. https://doi. org/10.1177/0959683613505346.

Moreno, P.I., Francois, J.P., Moy, C.M., Villa-Martínez, R., 2010. Covariability of the southern westerlies and atmospheric CO2 during the Holocene. Geology 38 (8), 727-730. https://doi.org/10.1130/G30962.1.

Nanavati, W.P., Whitlock, C., Iglesias, V., de Porras, M.E., 2019. Postglacial vegetation, fire, and climate history along the eastern Andes, Argentina and Chile (lat. 41-55 $\mathrm{S}$ ). Quat. Sci. Rev. 207, 145-160. https://doi.org/10.1016/j.quascirev.2019.01.014.

New, M., Todd, M., Hulme, M., Jones, P., 2001. Precipitation measurements and trends in the twentieth century. Int. J. Climatol. 21, 1922-1999. https://doi.org/10.1002/ joc. 680 .

Palma, S., Córdova, P., Silva, N., Silva, C., 2014. Biodiversity and spatial distribution of medusae in the magellan region (southern patagonian zone). Lat. Am. J. Aquat. Res. 42 (5), 1175-1188.

Pantoja, S., Iriarte, J.L., Daneri, G., 2011. Oceanography of the Chilean Patagonia. Continent. Shelf Res. 31, 149-153. https://doi.org/10.1016/j.csr.2010.10.013.

Pawłowska, J., Łącka, M., Kucharska, M., Szymańska, N., Koziorowska, K., Kuliński, K., Zajaczkowski, M., 2017. Benthic foraminifera contribution to fjord modern carbon pools: a seasonal study in Adventfjorden. Spitsbergen. Geobiol. 15 (5), 704-714. https://doi.org/10.1111/gbi.12242.

Porter, S.C., Stuiver, M., Heusser, C.J., 1984. Holocene Sea-level changes along the Strait of magellan and beagle channel, Southernmost South America. Quat. Res. 22, 59-67. https://doi.org/10.1016/0033-5894(84)90006-1.

Rebolledo, L., Lange, C.B., Bertrand, S., Muñoz, P., Salamanca, M., Lazo, P., Iriarte, J.L., Vargas, G., Pantoja, S., Dezileau, L., 2015. Late Holocene precipitation variability recorded in the sediments of Reloncaví Fjord $\left(41^{\circ} \mathrm{S}, 72^{\circ} \mathrm{W}\right)$, Chile. Quat. Res. 84 , 21-36. https://doi.org/10.1016/j.yqres.2015.05.006.

Rebolledo, L., Bertrand, S., Lange, C.B., Tapia, F.J., Quiroga, E., Troch, M., Silva, N., Cárdenas, P., Pantoja, S., 2019. Compositional and biogeochemical variations of sediments across the terrestrial-marine continuum of the Baker-Martínez fjord system (Chile, 48 ${ }^{\circ}$ S). Prog. Oceanogr. 174, 89-104. https://doi.org/10.1016/j. pocean.2018.12.004. 
Ríos, F., Kilian, R., Mutschke, E., 2016. Chlorophyll- $\alpha$ thin layers in the Magellan fjord system: the role of the water column stratification. Continent. Shelf Res. 124, 1-12. https://doi.org/10.1016/j.csr.2016.04.011.

Rostami, K., Peltier, W.R., Mangini, A., 2000. Quaternary marine terraces, sea-level changes and uplift history of Patagonia, Argentina: comparisons with predictions of the ICE-4G (VM2) model of the global process of glacial isostatic adjustment. Quat. Sci. Rev. 19, 1495-1525. https://doi.org/10.1016/S0277-3791(00)00075-5.

Rüggeberg, A., Flögel, S., Dullo, W., Raddatz, J., Liebetrau, V., 2016. Paleoseawater density reconstruction and its implication for cold-water coral carbonate mounds in the northeast Atlantic through time. Paleoceanography 31, 1-15. https://doi.org/ 10.1002/2015PA002859.

Ryan, W.B.F., Carbotte, S.M., Coplan, J., O'Hara, S., Melkonian, A., Arko, R., Weissel, R. A., Ferrini, V., Goodwillie, A., Nitsche, F., Bonczkowski, J., Zemsky, R., 2009. Global Multi-Resolution Topography (GMRT) synthesis data set. G-cubed 10 (3), Q03014. https://doi.org/10.1029/2008GC002332.

Saraswat, R., Kouthanker, M., Kurtarkar, S., Nigam, R., Linshy, V.N., 2011. Effect of salinity induced $\mathrm{pH}$ changes on benthic foraminifera: a laboratory culture experiment. Biogeosci. Discuss. 8, 8423-8450. https://doi.org/10.5194/bgd-8. 8423-2011, 2011.

Saunders, K.M., Roberts, S.J., Perren, B., Butz, C., Sime, L., Davies, S., Van Nieuwenhuyze, W., Grosjean, M., Hodgson, D.A., 2018. Holocene dynamics of the Southern Hemisphere westerly winds and possible links to $\mathrm{CO}_{2}$ outgassing. Nat. Geosci. 11, 650-655. https://doi.org/10.1038/s41561-018-0186-5.

Schneider, C., Glaser, M., Kilian, R., Santana, A., Butorovic, N., Casassa, G., 2003. Weather observations across the southern Andes at 53 ${ }^{\circ}$ S. Phys. Geogr. 24, 97-119. https://doi.org/10.2747/0272-3646.24.2.97.

Seidenkrantz, M.-S., Aagaard-Sørensen, S., Sulsbruck, H., Kuijpers, A., Jensen, K.G., Kunzendorf, H., 2007. Hydrography and climate change during the last 4,400 years in Ameralik Fjord, SW Greenland - implications for Labrador Sea palaeoceanography. Holocene 17, 387-401. https://doi.org/10.1177/ 0959683607075840.

Sepúlveda, J., Pantoja, S., Hughen, K.A., 2011. Sources and distribution of organic matter in northern Patagonia fjords, Chile $\left(\sim 44-47^{\circ} \mathrm{S}\right)$ : a multi-tracer approach for carbon cycling assessment. Continent. Shelf Res. 31, 315-329. https://doi.org/ 10.1016/j.csr.2010.05.013.

Silva, N., Vargas, C.A., 2014. Hypoxia in Chilean patagonian fjords. Prog. Oceanogr. 29, 62-74. https://doi.org/10.1016/j.pocean.2014.05.016.

Silva, N., Vargas, C.A., Prego, R., 2011. Land-ocean distribution of allocthonous organic matter in the surface sediments of the Chiloé and Aysén interior seas (Chilean Northern Patagonia). Continent. Shelf Res. 31 (3-4), 330-339. https://doi.org/ 10.1016/j.csr.2010.09.009.

Smeaton, C., Austin, W.E.N., 2017. Sources, sinks, and subsidies: terrestrial carbon storage in mid-latitude fjords. J. Geophys. Res.: Biogeosciences 122, 2754-2768. https://doi.org/10.1002/2017jg003952.

Smeaton, C., Austin, W.E.N., 2019. Where's the carbon: exploring the spatial heterogeneity of sedimentary carbon in mid-latitude fjords. Front. Earth Sci. 7, 269 https://doi.org/10.3389/feart.2019.00269.

Smeaton, C., Austin, W.E.N., Davies, A.L., Baltzer, A., Abell, R.E., Howe, J.A., 2016. Substantial stores of sedimentary carbon held in mid-latitude fjords. Biogeosciences 13 (20), 5771-5787. https://doi.org/10.5194/bg-13-5771-2016.

Smeaton, C., Austin, W.E.N., Davies, A.L., Baltzer, A., Howe, J.A., Baxter, J.M., 2017. Scotland's forgotten carbon: a national assessment of mid-latitude fjord sedimentary carbon stocks. Biogeosciences 14, 5663-5674. https://doi.org/10.5194/bg-14-56632017.
Smith, R.W., Bianchi, T.S., Allison, M., Savage, C., Galy, V., 2015. High rates of organic carbon burial in fjord sediments globally. Nat. Geosci. 8, 450-453. https://doi.org/ 10.1038 /ngeo2421.

Stern, C.R., 2008. Holocene tephrochronology record of large explosive eruptions in the southernmost Patagonia Andes. Bull. Volcanol. 70 (4), 435-454. https://doi.org/ 10.1007/s00445-007-0148-Z.

Sternbeck, J., Sohlenius, G., 1997. Authigenic sulfide and carbonate mineral formation in Holocene sediments of the Baltic Sea. Chem. Geol. 135, 55-73.

Stolpe, N., Undurraga, P., 2016. Long term climatic trends in Chile and effects on soil moisture and temperature regimes. Chil. J. Agric. Res. 76 (4), 487-496. https://doi. org/10.4067/S0718-58392016000400013.

St-Onge, G., Hillaire-Marcel, C., 2001. Isotopic constraints of sedimentary inputs and organic carbon burial rates in the Saguenay Fjord, Quebec. Mar. Geol. 176, 1-22. https://doi.org/10.1016/S0025-3227(01)00150-5.

Strub, P.T., James, C., Montecino, V., Rutllant, J.A., Blanco, J.L., 2019. Ocean circulation along the southern Chile transition region $\left(38^{\circ}-46^{\circ} \mathrm{S}\right)$ : mean, seasonal and interannual variability, with a focus on 2014-2016. Prog. Oceanogr. 172, 159-198. https://doi.org/10.1016/j.pocean.2019.01.004.

Torres, R., Frangopulos, M., Hamamé, M., Montecino, V., Maureira, C., Pizarro, G., Reid, B., Valle-Levinson, A., Blanco, J.L., 2011. Nitrate to silicate ratio variability and the composition of micro-phytoplankton blooms in the inner-fjord of Seno Ballena (Strait of Magellan, $54^{\circ} \mathrm{S}$ ). Continent. Shelf Res. 31 (3-4), 244-253. https:// doi.org/10.1016/j.csr.2010.07.014.

Torres, R., Silva, N., Reid, B., Frangopulos, M., 2014. Silicic acid enrichment of subantarctic surface water from continental inputs along the Patagonian archipelago interior sea (41-56 ${ }^{\circ}$ ). Prog. Oceanogr. 129, 50-61. https://doi.org/10.1016/j. pocean.2014.09.008.

Valdenegro, A., Silva, N., 2003. Caracterización oceanográfica física y química de la zona de canales y fiordos australes de Chile, entre el estrecho de Magallanes y Cabo de Hornos (Cimar 3 Fiordos). Cienc. Tecnol. del Mar 26 (2), 19-60.

Vargas, C.A., Martinez, R.A., San Martin, V., Aguayo, M., Silva, N., Torres, R., 2011. Allochthonous subsidies of organic matter across a lake-river-fjord landscape in the Chilean Patagonia: implications for marine zooplankton in inner fjord areas. Continent. Shelf Res. 31, 187-201. https://doi.org/10.1016/j.csr.2010.06.016.

Weidemann, S.S., Sauter, T., Kilian, R., Steger, D., Butorovic, N., Schneider, C., 2018. A 17-year record of meteorological observations across the Gran Campo Nevado Ice Cap in Southern Patagonia, Chile, related to synoptic weather types and climate modes. Front. Earth Sci. 6, 53. https://doi.org/10.3389/feart.2018.00053.

Yokoyama, Y., Maeda, Y., Okuno, J., Miyairi, Y., Kosuge, T., 2016. Holocene Antarctic melting and lithospheric uplift history of the southern Okinawa trough inferred from mid to late-Holocene sea level in Iriomote Island, Ryukyu, Japan. Quat. Int. 397, 342-348. https://doi.org/10.1016/j.quaint.2015.03.030.

Yu, Z., Loisel, J., Brosseau, D.P., Beilman, D.W., Hunt, S.J., 2010. Global peatland dynamics since the last glacial maximum. Geophys. Res. Lett. 37, L13402. https:// doi.org/10.1029/2010GL043584.

Ziegler, M., Nürnberg, D., Karas, C., Tiedemann, R., Lourens, L.J., 2008. Persistent summer expansion of the Atlantic Warm Pool during glacial abrupt cold events. Nat. Geosci. 1 (9), 601-605. https://doi.org/10.1038/ngeo277.

Zolitschka, B., Fey, M., Janssen, S., Maidana, N.I., Mayr, C., Wulf, S., Haberzettl, T., Corbella, H., Lücke, A., Ohlendorf, C., Schäbitz, F., 2019. Southern Hemispheric westerlies control sedimentary processes of Laguna Azul (south-eastern Patagonia, Argentina). Holocene 29, 403-420. https://doi.org/10.1177/0959683618816446. 